\title{
Late Cretaceous-Early Paleogene sandy-to-gravelly debris flows and their sediments in the Silesian Basin of the Alpine Tethys (Western Outer Carpathians, Istebna Formation)
}

\author{
Piotr STRZEBOŃSKI ${ }^{1, *}$ \\ 1 AGH University of Science and Technology, Faculty of Geology, Geophysics and Environmental Protection, Department \\ of General Geology and Geotourism, Al. A. Mickiewicza 30, 30-059 Kraków, Poland
}

Strzeboński, P., 2015. Late Cretaceous-Early Paleogene sandy-to-gravelly debris flows and their sediments in the Silesian Basin of the Alpine Tethys (Western Outer Carpathians, Istebna Formation). Geological Quarterly, 59 (1): 195-214, doi: 10.7306/gq.1183

The study focuses on Upper Cretaceous-Paleocene deposits from the Beskid Śląski mountain range in southern Poland constituting the Istebna Beds. The Istebna Beds, also referred to as the Istebna Formation, are part of the Silesian tectonic unit, which forms the Outer Carpathian fold-and-thrust belt (part of the Alpine-Carpathian system). The results of qualitative and quantitative lithological-sedimentological studies were the basis for the interpretation of lithofacies types, sedimentary processes and palaeoenvironment as well as for the reconstruction of the architecture of the depositional system. The analysis conducted on the basis of field description of the deposits shows the prevalence (nearly $70 \%$ ) of siliciclastic strata representing a sandstone-conglomerate association (S-C), which is the main subject of this work. The S-C lithofacies: sandstones, gravelly sandstones, sandy conglomerates and conglomerates constitute the deposits formed mostly by mass gravity-flows such as sandy-to-gravelly debris flows. The distribution of the coarse-clastic material indicates a sediment supply from southerly directions and implies the presence of an active source area in the rear part of the Silesian Basin. A succession of the sandstone-to-conglomerate deposits with the secondary participation of other lithofacies, with a thickness of approximately two thousand metres, indicates temporary increased diastrophic activity in the Silesian Ridge (source area) and the intense denudation of this area. The uplift of the alimentation area and its destruction coinciding with enforced relative regression and the uncovering of the proximal depositional zone of the basin led to resedimentation of the older intrabasinal material and repeated mass deposition together with delivery of extraclasts of pre-existing rocks and minerals. The lithofacies development of the sandstone-to-conglomerate debrites and the related sedimentary palaeotransport directions suggest an accumulation domain in the form of a linear apron depositional system developed in a deep-water setting. Experimental modelling of subaqueous sandy flows has contributed to a better understanding of the complex genesis of deep-water sediment gravity flows developing in depositional systems rich in sand material.

Key words: Flysch Carpathians, Silesian Nappe, Istebna Formation, sediment gravity flows, deep-water debris flows, apron depositional system.

\section{INTRODUCTION}

The Istebna Beds (sensu Burtanówna, 1936; Burtanówna et al., 1937), also referred to as the Istebna Formation (Menčík et al., 1983; Wójcik et al., 1996; Picha et al., 2006; Golonka and Waśkowska-Oliwa, 2007), constitute one of the informal lithostratigraphic divisions of the Silesian Unit of the Western Outer Carpathians (Figs. 1 and 2). The lithological-sedimentological features, ichnofacies characteristics and stratigraphic position of the deposits have been studied by a number of authors (e.g., Hohenegger, 1861; Liebus and Uhlig, 1902; Burtanówna, 1936; Burtanówna et al., 1937; Ksią kiewicz, 1962;

\footnotetext{
*E-mail: strzebo@geol.agh.edu.pl
}

Received: December 27, 2013; accepted: May 30, 2014; first published online: July 22, 2014
Unrug, 1963, 1968; Eliáš, 1970; Peszat, 1976; Menčík et al., 1983; Menčík and Tyráček, 1985; Ślączka, 1986; ytko et al., 1989; Poprawa et al., 2002, 2004; Strzeboński, 2005; Grzebyk and Leszczyński, 2006; Picha et al., 2006; Ślączka et al., 2006, 2012; Golonka and Waśkowska-Oliwa, 2007; Cieszkowski et al., 2009, 2012; Felix et al., 2009; Uchman, 2009; Rajchel and Uchman, 2012).

The sandstone-to-conglomerate deposits of the sedimentary succession analysed, and also similarly developed lithofacies in other formations (e.g., the Cię kowice Sandstone; Leszczyński, 1981), presumably due to their composite origins resulting from multifaceted sedimentary processes, were the subject of different interpretations in terms of both the mechanisms of sedimentary processes and the depositional systems. The geological nomenclature abounds in single terms attempting to define the frequently complex nature of these observed sedimentary bodies. Take for instance: fluxoturbidite (Dzulynski et al., 1959), atypical turbidite (Stanley and Kelling, 1978), high-density turbidite (e.g., Lowe, 1982), megaturbidite (Laba- 


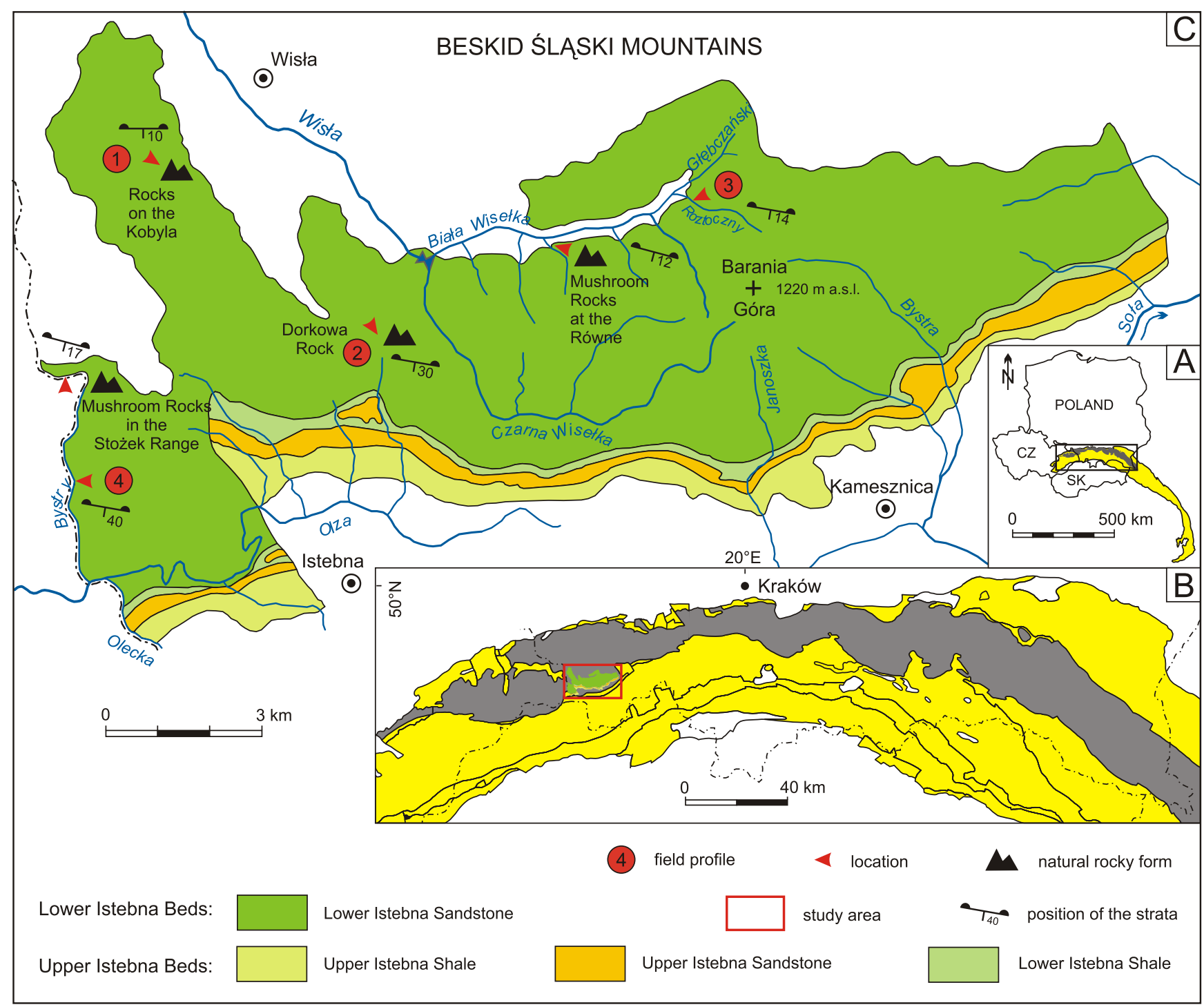

Fig. 1. The study area

A - position of the Outer Carpathian belt (yellow) and the Silesian Nappe (grey) relative to part of a contour map of Europe; B - location of the study area (Beskid Śląski Mts., red rectangle) relative to the Silesian Nappe (grey) in the Western Outer Carpathians; C - outcrop of the Istebna Formation (without Quaternary formations) in the Beskid Śląski Mts. (after Burtan et al., 1956; Burtan, 1972; ytko et al., 1989; Lexa et al., 2000; Cieszkowski et al., 2012; partly modified)

ume et al., 1987), often associated with a conventional submarine fan model (sensu Mutti and Ricci Lucchi, 1972) as their main depositional system.

The concept, for example, of fluxoturbidites, was originally coined for the Istebna Beds by Dzulynski et al. (1959), although the same authors emphasized the role of "sand avalanches" in the formation of the succession. Unrug (1963), who investigated the succession, even added that "The Istebna beds (Campanian-Paleocene in the Silesian series) are perhaps the best example of a formation differing in sedimentary character from a typical turbidite flysch" and also "The sandstones are clean and not muddy as in typical turbidites".

Deep-water depositional environments are not limited to turbidite systems (mainly formed by turbidity current deposits) (see Fig. 3B; see also Strzeboński and Słomka, 2007) for which submarine fans (sensu Mutti and Ricci Lucchi, 1972) are models commonly used in interpretation. They also include other depositional systems, where different gravity-driven sedimentary processes play a much greater or dominating role (e.g., Shanmugam and Moiola, 1988; Reading and Richards, 1994; see also Strzeboński, 2009). Sedimentation of deep-water siliciclastic deposits in slope-apron depositional systems is referred in the literature as an alternative to deposition in turbidite systems of submarine fans (see e.g., Reading and Richards, 1994; Słomka, 1995; Strzeboński, 2005).

In the early 1960s, conglomerates and certain types of sandstones of the Istebna Beds were interpreted by Unrug (1963) as deposited by subaqueous sand flows moving as submarine slope-avalanches which partially transformed into turbidity currents. Unrug (1963) also defined the depositional system of these sandstone and conglomerate deposits as a group of overlapping and weakly individualised submarine fans forming at the outlets of submarine chutes or canyons and entering the area of the Subsilesian Series sedimentary basin. However, 


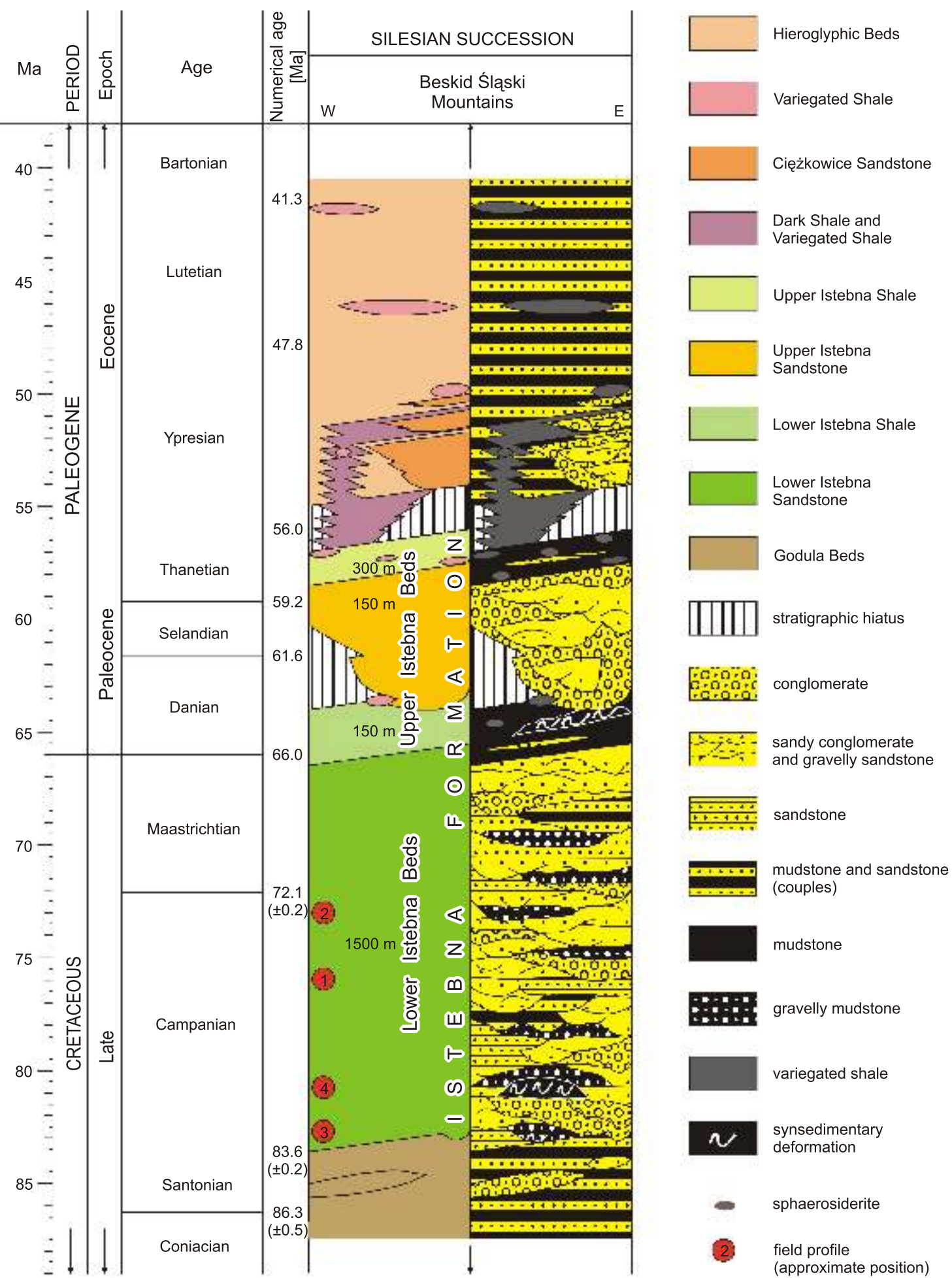

Fig. 2. Scheme of lithostratigraphic units for the Upper Cretaceous-Eocene part of the Silesian Succession in the Beskid Śląski Mts. (after: Burtanówna et al., 1937; Geroch, 1960; Nescieruk and Szydło, 2003; Strzeboński, 2005; Wagner, 2008; Cohen et al., 2013; partly changed)

"...slumps developing in the sedimentary apron covering the steep submarine slopes..." (generated mud flows) were mentioned.

The massive sandstones could potentially be formed by different types of deep-water sediment gravity flow under the influence of various sedimentary processes, but their origins are not yet well-established. For example, according to Lowe (1982) or Talling et al. (2012), they may be deposited by high-density turbidity currents (interpreted as deposits similar to Ta division of the Bouma sequence; Bouma, 1962) and in an en masse fashion by poorly- or non-cohesive liquefied debris flow (high sediment concentration flow, laminar plug). Yet another origin was 

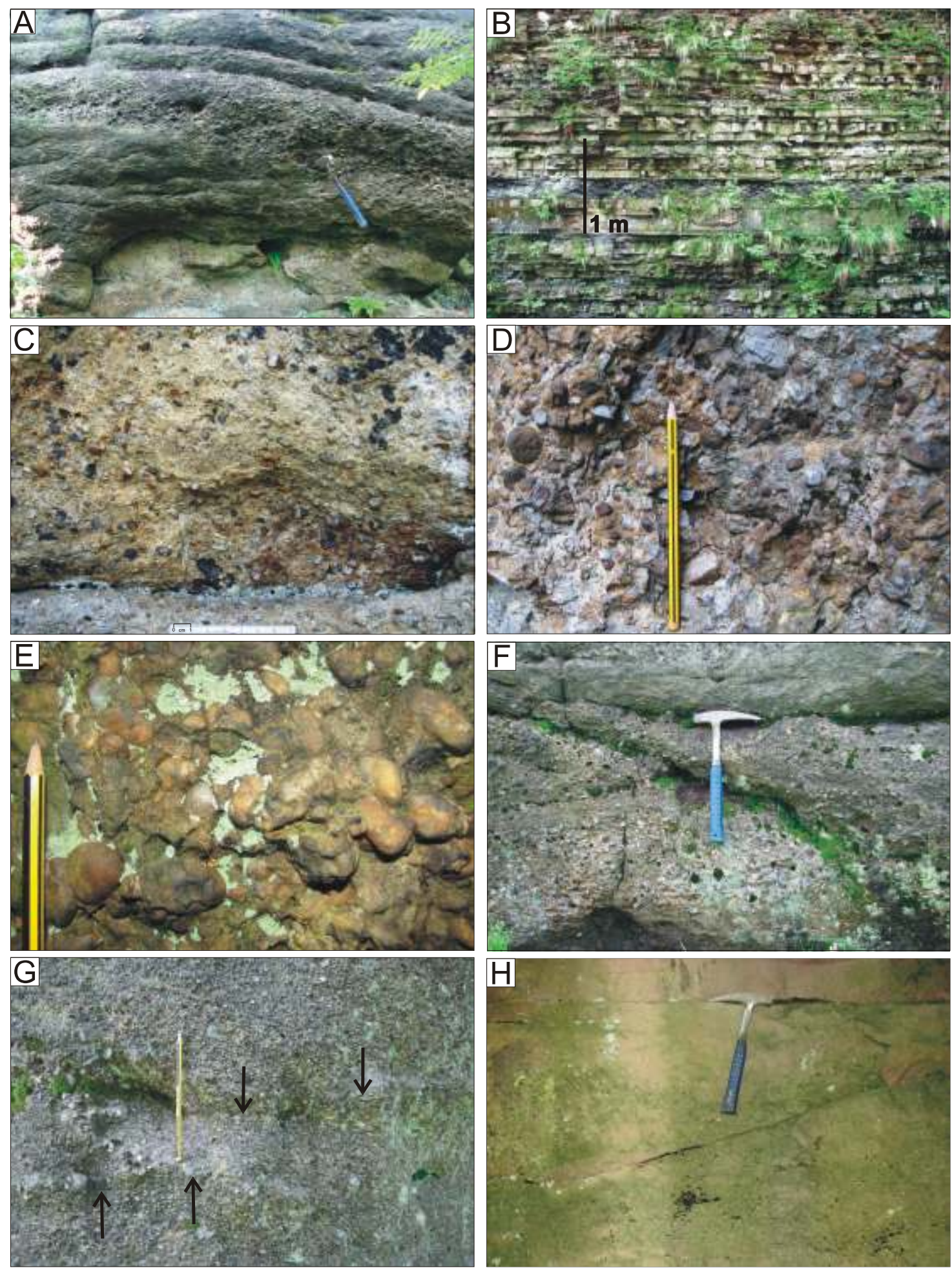

Fig. 3. Selected lithological-sedimentological features of sandstone-conglomerate debrites (S-C deposits) from the Istebna Formation in the Beskid Śląski Mts. (except for Fig. 3B)

A - composite series of massive debrite deposits, dominated by gravelly sandstone with lenticular conglomerate intercalations (Mushroom Rocks in the Sto ek Range; see Strzeboński, 2012c); B - regularly bedded, normal-graded and ripple cross-laminated deposits of the SM and MS lithofacies by comparison with the sandstone-conglomerate debrites from the Istebna Formation (Godula Formation in the Biała Wisełka River valley; see Strzeboński and Słomka, 2007); C - ungraded gravelly debrite sandstone with quartz granules and fine pebbles "floating" in a poorly sorted sandy matrix (random fabric; Rocks on the Kobyla; see Strzeboński, 2012d); D - massive debrite conglomerate consisting of poorly sorted quartz and exotic clasts randomly scattered in a sand-rich matrix (Dorkowa Rock; see Strzeboński, 2012a); E - clast-supported conglomerate with moderately sorted quartz pebbles, channel lag? (Mushroom Rocks in the Sto ek Range; see Strzeboński, 2012c); F sloped surface of submarine erosion (beds pinch out) and fragment of channel-fill in the apron sheet (Mushroom Rocks in the Sto ek Range; see Strzeboński, 2012c); G - amalgamation of massive sandy conglomerate beds showing faint amalgamation surfaces emphasized by weathering (Mushroom Rocks in the Sto ek Range; see Strzeboński, 2012c) (indicated by arrows); H - a fragment of a small channel; visibly sloping erosion surface below the hammer and gravelly fill in the axial part of the chute (north-west rise of the Sto ek Range) 
offered by Shanmugam et al. (1985) supported by laboratory research and detailed field observation (see also Shanmugam, 2012). Shanmugam et al. (1985) interpreted massive sandstone deposits (see e.g., Fig. 3C) as deposited by sandy debris flows in connection with slope depositional models (see also Stow and Johansson, 2000; Purvis et al., 2002; Duranti and Hurst, 2004)

Sandstone debrites and other deposits associated with gravity-driven processes (e.g., sandy- and muddy slides/slumps or muddy debris flows) have been recognized in numerous connate deep-water depositional systems (Shanmugam, 2006, 2012). There are also numerous documented examples of the domination of mass sedimentation type siliciclastics (i.e., slides, slumps and debris flow deposits) in modern subaqueous sedimentary environments (e.g., Gardner et al., 1996, 2000; Elverhoi et al., 1997; Shanmugam, 1997; Klaucke et al., 2004; Tripsanas et al., 2004). As it transpires, however, the composite nature of the deposits of deep-water gravity-driven processes and possible transformations of their types (see e.g., Unrug, 1963; Fisher, 1983; Shanmugam, 2006; Felix et al., 2009; Mulder, 2011), terminology and genesis still trigger much debate among experts (see e.g., the discussion between Shanmugam, 2010 and Mutti et al., 2010; see also Mulder, 2011; Talling et al., 2012; Shanmugam, 2012).

The aim of this paper is to provide a qualitative and quantitative description of the Istebna Formation deposits from the Beskid Śląski Mountains, characterize the sediment gravitydriven processes and their sediments, interpret the genesis of selected lithofacies (specifically the sandstone-conglomerate association - S-C) and reconstruct their sedimentary environment and the development of their depositional system.

This work is dedicated to the memory of the outstanding Polish geologist and sedimentologist Rafał Unrug, professor at the Jagiellonian University (see Ślączka et al., 2001).

\section{DATABASE, METHODOLOGY AND BASIC CONCEPTS}

The present case study is based on the investigation of over 3800 metres of true vertical bed thickness in total exposed in brooks, rivers, quarries and natural rocky forms (tors) (Fig. 1).

The interpretation of the types of lithofacies, processes of transportation and deposition of sediments and their properties (e.g., fluid rheology, flow state and sediment-support mechanism), sedimentary environment and depositional system, and palaeogeography was conducted mainly on the basis of results of sedimentological facies analysis (e.g., Reading, 1986; Shanmugam, 2006, 2012; Mulder, 2011; Talling et al., 2012). This analysis consisted mostly of field observations and description of exposures (lithological-sedimentological logging of outcrops). Next, attempts were made to establish the relations between the following: lithology, lateral and vertical spread of deposits, spatial distribution of clastic bodies, lithosome geometry, succession of deposits (organised sequences or chaotic units), sedimentary structures (types of depositional intervals), directions of sediment palaeotransport (type of alimentation, i.e., point, multipoint or linear - Reading and Richards, 1994). Finally, the elements interpreted were compared with their ancient and modern "equivalents".

The abbreviations of lithofacies applied correspond with the first letters of lithological terms in English, for instance, CS sandy conglomerate (see e.g., Ghibaudo, 1992; Słomka, 1995; Strzeboński, 2005). Due to the scarcity of directional sedimen- tary structures in sandstone-to-conglomerate debrites, the directions of sedimentary palaeotransportation were defined on the basis of the imbrication of clasts, flame structures, the arrangement of long clast axes or the direction of wash-outs and erosional channels (chutes) axes. The orientation of strata was measured for each palaeocurrent direction measurement. Research was archived using traditional methods (notebook, photography) as well as slightly modified forms, for example a sedimentological log sheet for description of exposures (Kotlarczyk et al., 1997; see also Shanmugam, 2006). The grade and class terminology of grain size was used after Wentworth (1922), roundness after Powers (1953), and bed thickness after Campbell (1967).

The term deep-water sedimentary environment is applied in reference to the sea palaeoenvironment of slope, rise and basin plain as opposed to a shallow-marine sedimentary environment connected with the shelf (see e.g., Shanmugam, 2006; Mulder 2011).

In this paper the term flysch is used to denote a thick (varying from hundreds to thousands of metres) outer-Carpathian successions containing siliciclastic deposits, formed by sedimentary gravity-driven processes in a deep-water setting.

The term deep-water submarine slide is used to delineate a gravity-driven process, a type of translational mass movement. Slide deposit takes the form of a coherent unit without internal deformation. Downslope mass transport occurs along a shear zone with a basal planar glide plane (see Shanmugam, 2006).

A deep-water submarine slump is a gravity-driven process, a type of rotational mass wasting. Slump deposit tends to be structured in a coherent, partly lithified, plastically flexible sediment mass with internal deformation (folds, deformation lobes), where original bedding can be partially destroyed. Downslope mass transport takes place along a shear zone with a basal concave-up glide plane (see Shanmugam, 2006).

Deep-water sandy-to-gravelly debris flows (sandy-, sandy gravelly-, gravelly sandy- and gravelly debris flows) are one of the gravity-driven sedimentary processes representing downslope mass flows as an aggregate of free particles (incoherent grain elements), composing a grain-water mixture (predominantly sand and gravel, i.e., cohesionless debris).

The physical properties of the sandy-to-gravelly debris flows are as follows:

- rheology - non-Newtonian, quasi-plastic (hydro-plastic) mechanical behaviour;

- flow state - quasi-laminar (i.e., non-turbulent);

- dominant sediment-support mechanisms - sandy grain fabric strength (in sandy- and sandy-gravelly debris flows), sandy matrix strength (in gravelly-sandy- and gravelly debris flows with sand-rich matrix), buoyancy (buoyant lift), dispersive pressure (predominant intergranular movements - collisions) or upward flow though often a mix of these;

- sediment concentration - high (25-95\% by volume);

- mud content - almost none, low to medium (i.e., from $<1$ to 25 vol.\%; poorly cohesive muddy matrix randomly scattered in an essentially non-cohesive sandy-gravelly aggregate);

- deposition - mainly en masse by frictional freezing (relatively abruptly), less often incrementally (hindered settling).

Deposits of the sandy-to-gravelly debris flows are moderately- to poorly sorted sandstone-to-conglomerate debrites, id est, sandstone- (Figs. $3 \mathrm{H}$ and 4A), gravelly sandstone- (Figs. $3 \mathrm{C}$ and $4 \mathrm{~B}$ ), sandy conglomerate- (Figs. 3G and 4D) and con- 

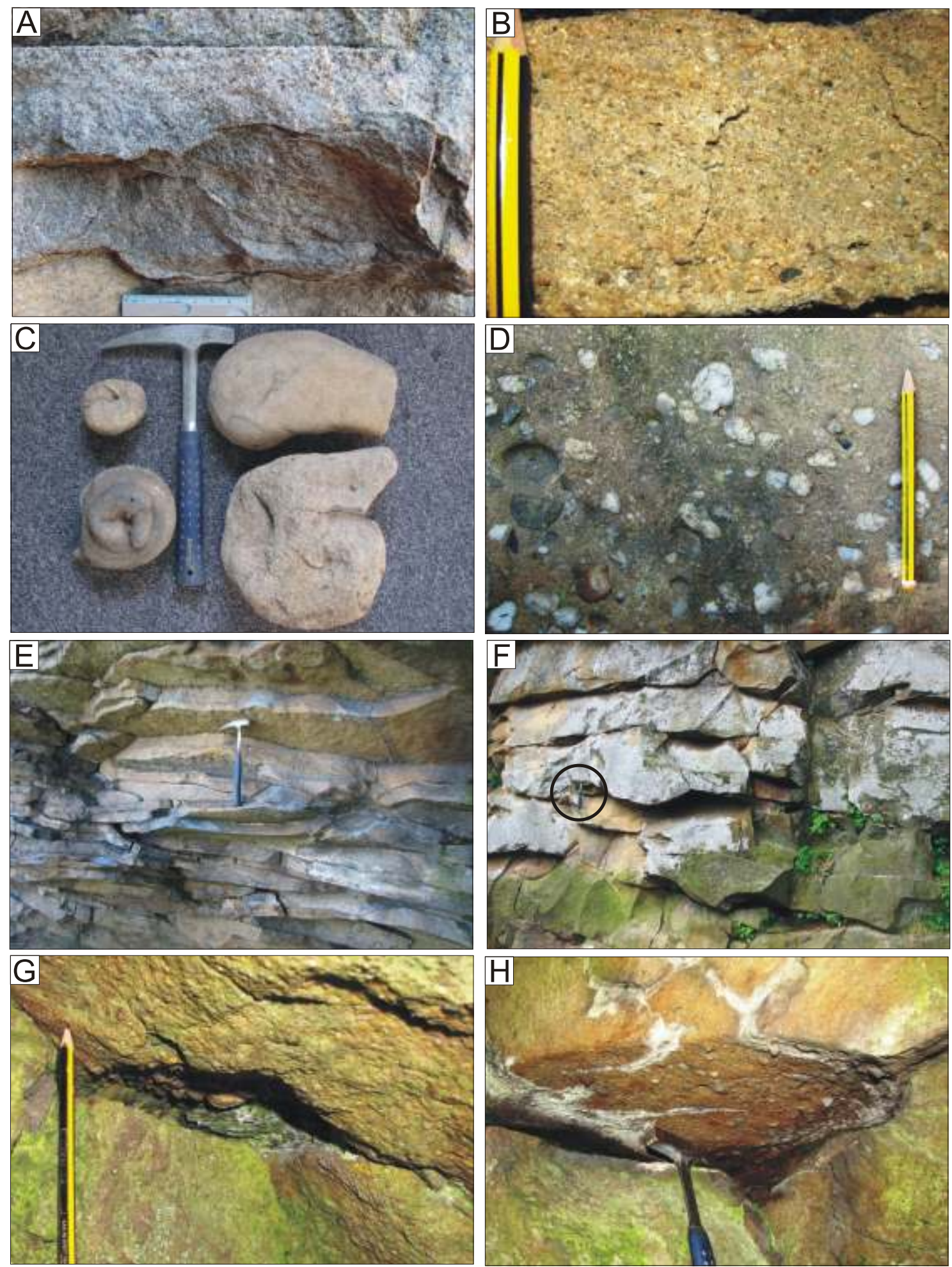

Fig. 4. Selected lithological-sedimentological features characteristic of the sandstone-conglomerate debrites (S-C deposits) from the Istebna Formation, Beskid Śląski Mts.

A - four, partly amalgamated, moderate to moderately good sorted layers of massive sandstone debrite (Sto ek Range); B - gravelly debrite sandstone, whitish feldspar grains visible among quartz grains (Mushroom Rocks at the Równe; see Strzeboński, 2012b); C - "ammonite" structure (pieces from Bystra River); geological hammer for scale is 13 " (33 cm); D sandy debrite conglomerate (sandy matrix-supported conglomerate), quartz gravel pebbles "floating" in very poorly sorted sand-rich matrix (Bystra River); E - a series of thinly- to medium-bedded sandstone debrites without mudstone intercalations (Rocks on the Kobyla; see Strzeboński, 2012d); F - a series of thick- to very thick beds, irregularly bedded sandstone-conglomerate debrites without mudstone intercalations (Rocks on the Kobyla; see Strzeboński, 2012d); geological hammer (in black circle) for scale; $\mathbf{G}$ - interbed surface with lenticular accumulation of mudstone clasts and quartz pebbles (Dorkowa Rock; see Strzeboński, 2012a); H - quartz gravel armoured mudstone balls (Dorkowa Rock; see Strzeboński, 2012a) 
glomerate debrites (Fig. 3D, E). The deposits are mostly massive (e.g., Fig. 3C-E), but also may show inverse-, and/or inverse to normal size-grading (i.e., pensymmetric depositional structure) and with common amalgamation of beds (Fig. 3F, G), as well as other features mentioned in the summary of this work. The geometry of the debrite deposits takes the form of tongue-like, lenticular, medium to very thick bodies (Figs. 3A, F and $4 \mathrm{E}, \mathrm{F}$ ), which underwent coalescence and formed "amalgamated" in large-scale high-relief apron sheets (siliciclastic covers). The debrites generally form chaotic (without depositional sequences) and composite sedimentary series and/or may locally constitute channel (chute) fillings (Fig. 3F, H) and lobe-like bodies at the outlets of these channels (compiled after Reading and Richards, 1994; Shanmugam, 2000, 2006; Gani, 2004; Mulder, 2011 and the author's observations).

A deep-water turbidity current is a fluid-sediment-gravity flow process without flow strength (only low-density water-sediment slurry). The physical properties of the turbidity current:

- rheology - Newtonian (fluidal), viscous mechanical behavior;

- flow state - turbulent;

- principal particle-support mechanism - water-supported particles in fully turbulent suspension (fluid turbulence);

- sediment concentration - 1-23 vol.\% (i.e., only low-density flow);

- mud content - 13.5-34.5 vol.\%;

- deposition - progressive suspension settling (aggradation grain-by-grain).

Deposits of turbidity currents are turbidites (sandstoneand/or mudstone turbidites). The sedimentary structures of the deposits comprise single, simple layers, i.e., not composite, not lenticular but laterally continuous with a relatively constant but small thickness (generally thin to medium; Fig. 3B), clearly marked erosive base and frequently occurring flute casts, only a single normal size-grading (single waning depositional event) and (e.g., generally only normal graded Ta member of the Bouma sequence, Bouma, 1962), very fine to medium grainsize sandstone beds, usually interbedded with mudstones (gradational lower contact; Fig. 3B), without "floating" or rafted mudstone clasts and planar- and/or random clast fabric of quartz gravels (Fig. 4D), as well as without outsized clasts (inside and at the top), also without armoured mudstone clasts and armoured mudstone balls (Fig. 4G, H). The geometry of the deposits involves bedding regularly and relatively continuous over long distances, low-relief basin plain sheets, radial fan lobes, lobe fringes and/or fan fringes, frequently negative sequences (compiled after Kuenen, 1957; Sullwold, 1961; Bouma, 1962; Dott, 1963; Sanders, 1965; Mutti and Ricci Lucchi, 1972; Middleton and Hampton, 1973; Reading and Richards, 1994; Sanders and Friedman, 1997; Shanmugam, 2000, 2006, 2012; Gani, 2004; Mulder, 2011 and own observations).

For the purpose of field descriptions, two basic bed types were distinguished: a single bed (in a slightly different sense than the simple beds of Leszczyński, 1989) and a complex bed (sensu Unrug, 1963, essentially similar to the composite beds of Leszczyński, 1989). Single beds and complex beds form depositional series.

The term single bed is applied to denote a distinct layer of a sedimentary deposit occurring as an individualised (individual) body in the lithofacies succession, bounded at the base and top by obvious bedding planes (visible sedimentary bed boundaries or erosional surfaces), displaying simple composition in terms of textural features and sedimentary structures and with- out any internal discontinuities (erosion surfaces), possibly indicating their monogenesis (single sedimentary event and/or single depositional process).

The term complex bed is applied in reference to an individual sedimentary body consisting of at least two often amalgamated single beds, comprising internal discontinuities, bounded at the bottom and top by obvious sedimentary bed boundaries or erosional surfaces, possibly suggesting a composite origin (single event and multifaceted sedimentary processes or separate sedimentary events and single- and/or multi-sedimentary processes)

\section{AN OUTLINE OF THE GEOLOGICAL SETTING AND PREVIOUS STUDIES}

The name Istebner-Sandstein was introduced by Hohenegger (1861) to define light-coloured conglomerates and dark-coloured mudstones with "exotics", occurring in the Beskid Śląski Mts. to the south of the Barania Góra Mountain (Fig. 1). The suggested lithostratigraphic unit, dated as Cenomanian, at the time represented the approximate equivalent only of the Upper Istebna Beds of the Silesian Succession in their modern understanding (sensu Burtanówna, 1936; Burtanówna et al., 1937; Figs. 1 and 2), but also partly comprised deposits currently not included in the Silesian Nappe (cf., Hohenegger, 1861; Burtan et al., 1956; Burtan, 1972). Continued lithostratigraphical research in the Western Beskidy Mountains resulted in the expansion of the range of the Istebna Beds and their division into two parts (Liebus and Uhlig, 1902). Uhlig (in Liebus and Uhlig, 1902) considered Hohenegger's Istebner-Sandstein to be the upper part of the newly defined lithostratigraphic unit of the Istebna Beds and included the upper part of Hohenegger's Godula-Sandstein as bottom unit of this newly defined formation, and specified the age as Cenomanian-Turonian. Subsequent subdivision of the Istebna Beds in the stratotype section of the Beskid Śląski Mts. was made by Burtanówna (1936). She proposed adopting Uhlig's lower level of the Istebna Beds as the Lower Istebna Beds, and calling them the Lower Istebna Sandstones (due to the prevalence of sandstone), while Uhlig's upper part of the Istebna Beds would be termed the Upper Istebna Beds. She also subdivided the Upper Istebna Beds into three parts (according to the prevalent lithological characteristics). The lowest part of the Upper Istebna Beds (mostly mudstone) was called the Lower Istebna Shales, the middle section (mostly sandstone-conglomerate) was the Upper Istebna Sandstones, and the uppermost part (mostly composed of mudstone shales including beds with clayey sphaerosiderites) was the Upper Istebna Shales (Burtanówna, 1936; see also Burtanówna et al., 1937; Burtan, 1973; see Fig. 2).

The Istebna Formation deposits are found in the Beskid Śląski Mts. and mainly in the southern part of the Silesian Nappe (Fig. 1B; e.g., Burtan et al., 1956; Burtan, 1972). In the tectonic structure of this part of the nappe one may distinguish two parts which differ in their lithofacies development and geological setting (Unrug, 1969). The lower part - the Cieszyn Subunit (sub-nappe) is composed of the relatively flexible, tectonically susceptible, very intensely folded Cieszyn Beds deposits (Ksią kiewicz, 1972; Vendryně Formation and Cieszyn Limestone Formation sensu Golonka et al., 2008), whereas the upper part - the Godula Subunit (sub-nappe) is composed of thick (1500-2000 m) and structurally rigid sandstone-mudstone and conglomeratic flysch succession of the Godula Beds (Burtanówna et al., 1937; Słomka, 1995; Godula Formation 
sensu Menčík, 1983; Wójcik et al., 1996; Picha et al., 2006; Golonka and Waśkowska-Oliwa, 2007) and also predominantly sandstone-conglomerate- (total up to $1650 \mathrm{~m}$ ) and secondarily mudstone flysch succession of the Istebna Beds (total up to 450 m; Figs. 1 and 2; see Unrug, 1963; Ksią kiewicz, 1972; ytko et al., 1989; Paul et al., 1996). In the Carpathians, the Istebna Formation reaches its greatest thickness (up to 2100 $\mathrm{m}$ ) and full development, reflected in the aforementioned four parts (see Fig. 2) in the Beskid Śląski Mts. (Fig. 1; Burtanówna et al., 1937; Burtan, 1973; Unrug, 1963; Strzeboński, 2005).

At the boundary between the Istebna Formation and the underlying Godula Formation, transitional deposits occur with lithological and structural features typical of both formations. However, these deposits are classed as the highest part of the Upper Godula Beds (Burtanówna et al., 1937; Burtan, 1973). Above the Istebna Formation, there is the "Submenilite Paleogene" flysch (Leszczyński, 1981; Rožnov Formation sensu Picha et al., 2006). It develops as lenticular lithosomes of sandstone-conglomerate deposits interbedded with variegated shales - the Cię kowice Sandstone (Burtanówna et al., 1937; Leszczyński, 1981; the Cię kowice Formation sensu Wójcik et al., 1996) and the Hieroglyphic Beds (Burtanówna et al., 1937; Hieroglyphic Formation, cf., Wójcik et al., 1996) with intercalations of variegated shales (Fig. 2).

One of the characteristic features of the Istebna Formation deposits are clasts of pre-existing rocks: igneous, metamorphic and sedimentary. Such clasts were defined by Hohenegger (1861) as exotics. Exotic clasts can constitute components of both gravelly mudstone and sandstone-to-conglomerate deposits (see Strzeboński, 2005). To date, research on exotics from the Istebna Beds has been conducted mainly with regard to their mineralogical and petrographic composition, the origin of their source areas (e.g., Ksia kiewicz, 1953, 1962; Unrug, 1963, 1968; Unrug, 1969; Peszat, 1976; Peszat and Wieser, 1999), micropalaeontological microfacies and palaeoenvironmental character (e.g., Burtan et al., 1984), and isotope geochronology (e.g., Poprawa et al., 2004).

The age of the Istebna Formation in the Beskid Śląski Mts. has been determined as Campanian-Paleocene (Fig. 2; e.g., Geroch, 1960; see also Nescieruk and Szydło, 2003; Wagner, 2008), mainly on the basis of micropalaeontological and rare macrofossil investigations.

\section{LITHOFACIES}

For the purpose of describing the Istebna Formation of the Beskid Śląski Mts., several basic sedimentary lithofacies types have been distinguished (see: Ghibaudo, 1992; Słomka, 1995; Strzeboński, 2005):

- conglomerate $(C)$ - volumetric prevalence of grain components coarser than $2 \mathrm{~mm}$ (i.e., gravel framework), frequently medium-grained (4-32 mm; Fig. 3D, E);

- sandy conglomerate (CS) - poorly sorted, ungraded, sandy matrix-supported (Figs. 3G and 4D);

- gravelly sandstone (SG) - sandstone with dispersed components of the psephitic fraction, frequently massive (Figs. 3C and 4B);

- sandstone (S) - different sublithofacies, frequently coarse-grained $(0.5-1.0 \mathrm{~mm})$ and massive (Figs. $3 \mathrm{H}$ and $4 \mathrm{~A}$ );

- mudstone $(\mathrm{M})$ - frequently massive or thinly parallellaminated (different sublithofacies);

- sandstone-mudstone couplet (SM) - a couplet of deposits where the sandstone bed is thicker than the superimposed mudstone, the sandstone showing sharp base, normal size grading and/or lamination (most frequently as small-scale ripple cross-lamination) in the upper part and mudstone showing gradational lower contact (Fig. 3B, upper part of the photograph);

- mudstone-sandstone couplet (MS) - M>S, similar elements as in SM only in different proportions (Fig. 3B, the lowest part of the photo);

- gravelly mudstone (MG) (sensu pebbly mudstone; D ułyński and Radomski, 1955; Crowell, 1957) mudstone containing randomly scattered granules, pebbles, cobbles, boulders, locally with a higher concentration of gravelly components in the basal part of the bed or outsized clasts at the top (see Strzeboński, 2005).

This study focuses primarily on the deposits distinguished as lithofacies S, SG, CS and C, which are collectively referred to as the sandstone-conglomerate lithofacies association - S-C (see Figs. 3A, C-H, 4A, B, D-H, 5 and 6). Deposits of the S-C mostly occur in the succession of the Lower Istebna Sandstones (ca. $80 \%$ thickness, with over $70 \%$ of lithofacies S+SG; Fig. 2) and the Upper Istebna Beds, almost entirely composed of the S-C deposits (Fig. 2). The proportion of selected lithofacies is shown in the table below (Table 1).

\section{LITHOLOGICAL AND SEDIMENTOLOGICAL CHARACTERISTICS OF THE SANDSTONE-TO-CONGLOMERATE DEPOSITS}

The deposits of the sandstone-conglomerate lithofacies association (S-C) consist mainly of quartz grains and an admixture of feldspars (Fig. 4B). The sandstones frequently exhibit moderate or moderately good sorting (Figs. 3H and 4A) and rounded grains. Non-kaolinised feldspar grains may be partly angular (Fig. 4B). The SG, CS and C lithofacies include subrounded to rounded grains and are usually poorly sorted (Figs. $3 D, E$ and 4D). A light colour is typical of all deposits of the S-C. The deposits reveal yellowish, beige and rusty shades on weathered surfaces (Figs. 3E and 4B), which results from the presence of iron compounds in the detrital, clay and sericite matrix (Unrug, 1968). On fresh surfaces, the S-C deposits are bright grey and bluish. The deposits usually show a massive structure (no grading or lamination) (Figs. 3C, D, 5 and 6). In the case of C, CS and SG lithofacies, scattered quartz granules and pebbles mostly "float" in the sandy matrix (Figs. 3C, D and 4D). There are also gravelly lenses (Fig. 3A) and gravelly fillings of "pockets" (Figs. 5 and 6). Locally gravel forms distinct, plane-parallel laminated horizons. A concentrated accumulation of larger components may occur in the basal part of beds (Figs. 5 and 6). Pensymmetric grading and inverse grain-size distribution are also observed (Figs. 5 and 6) but normal grading occurs less frequently. Bed surfaces are usually uneven, "undulating" and commonly sharp-edged (Figs. 4E, F, 5 and 6). What is characteristic of the S-C deposits is a general lack of trend changes (ordered sequences - positive and/or negative) in the succession of beds (Figs. 4F, 5 and 6). Directional, systematic changes involving a decrease in grain-size and/or thickness in subsequent beds can occur in the form of single or multiple concave fills, channel-like bottom forms (Figs. 5 and 6). Sometimes a decrease in grain-size with a concurrent increase in the thickness of subsequent beds is also observed. Mudstone clasts, usually randomly scattered within the bed, occur in the S-C deposits. Mudstone clasts less often assemble in certain layers within the bed, forming a kind of stratification or concentration on the bed surface. Mudstone clasts in places take the form of quartz-granule- and pebble-armoured mudstone balls (with an elliptical cross-section) up to 60 centimetres in longer axis (Fig. 4H). Parallel alignment of long clast axes, resembling current lineation, was also noted. Dewatering struc- 

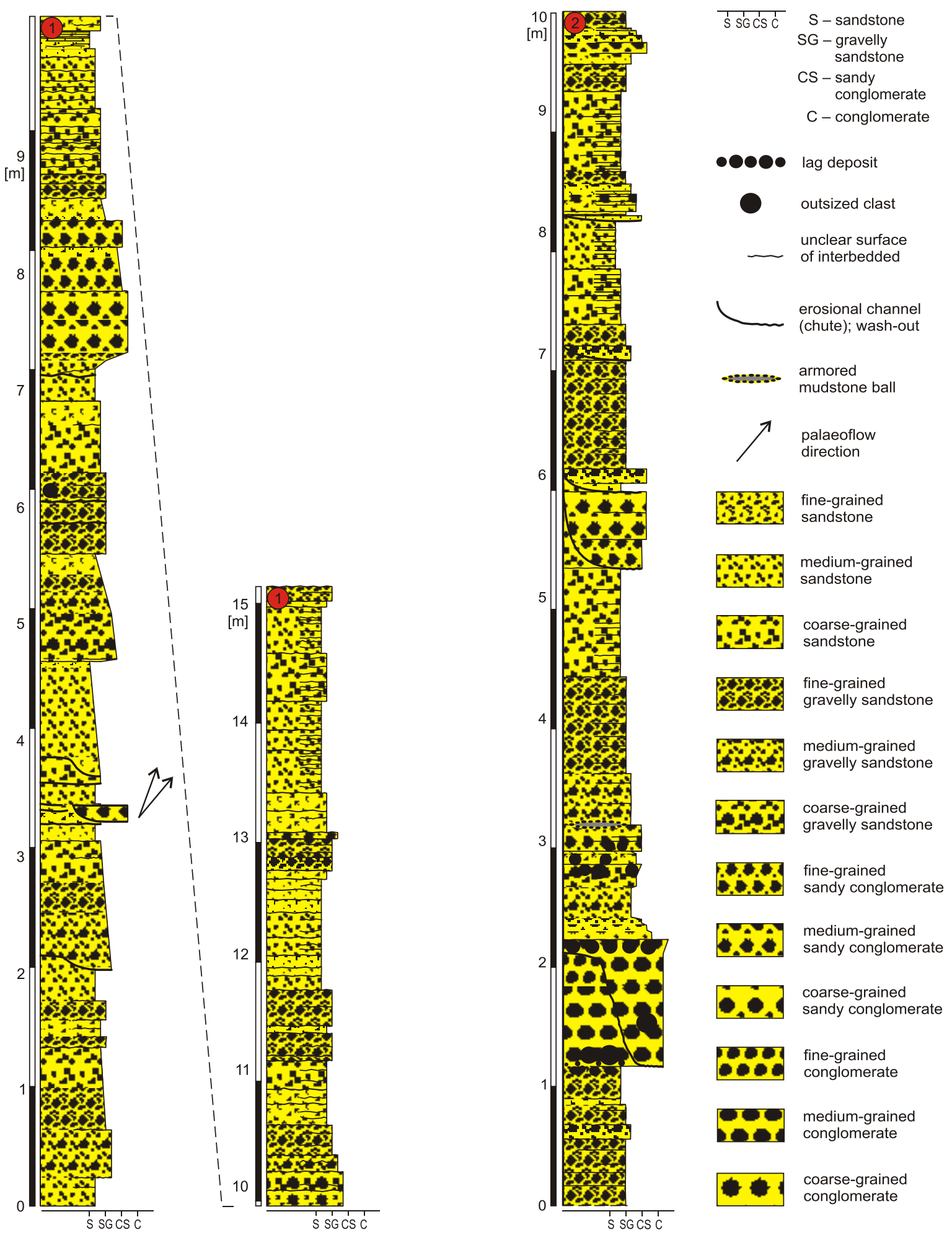

Fig. 5. Schematic lithological-sedimentological logs showing examples of development representative of sandstone-to-conglomerate debrites (S-C deposits) from the Istebna Formation in the Beskid Śląski Mts.

1 - Rocks on the Kobyla section (see Strzeboński, 2012d); 2 - Dorkowa Rock section (see Strzeboński, 2012a); for location see Figures 1 and 2 

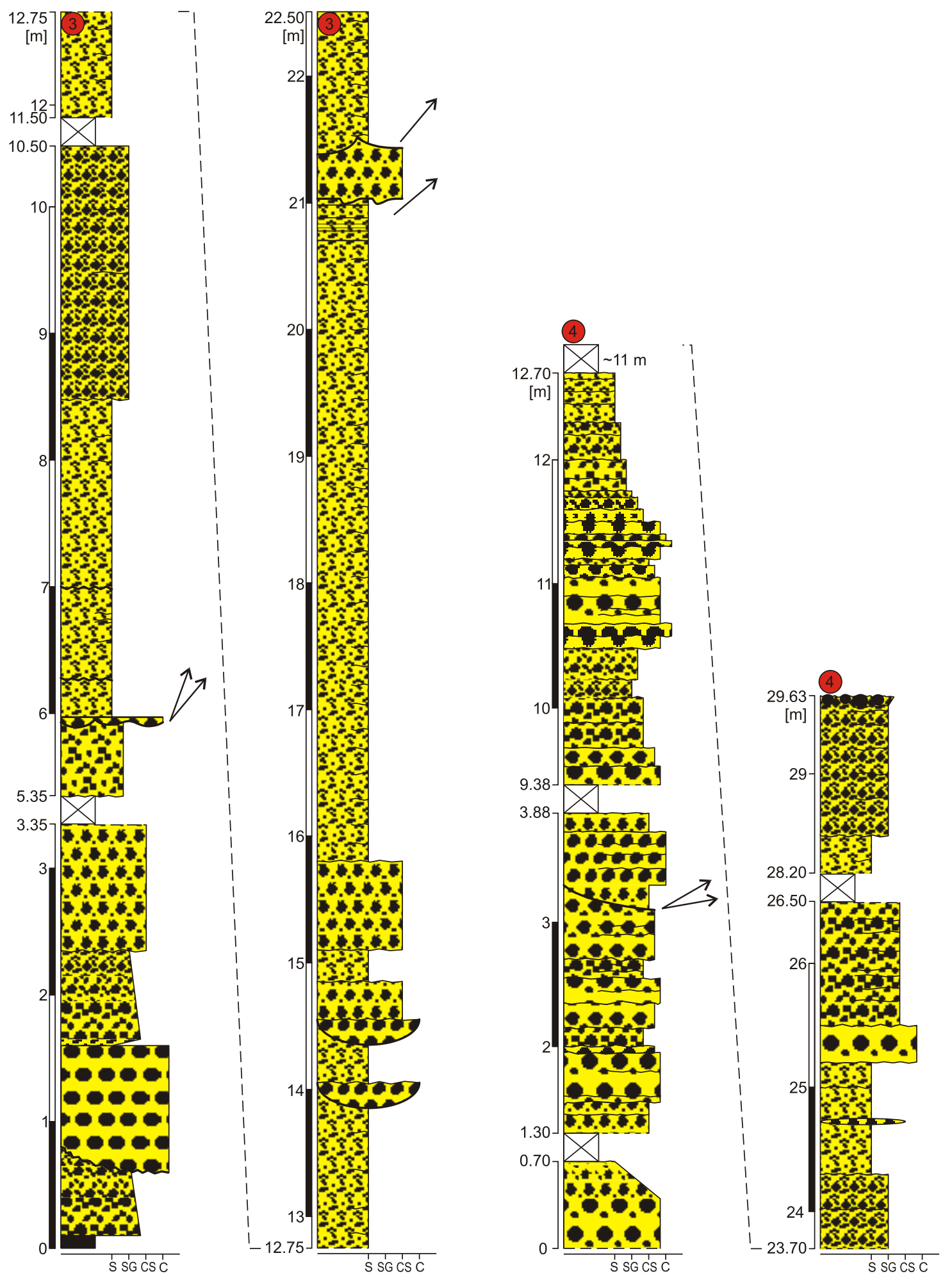

Fig. 6. Schematic lithological-sedimentological logs showing example of typical sandstone-conglomerate debrites (S-C deposits) from the Beskid Ślaski Mts.

3 - Roztoczny River section (Wisła-Czarne); 4 - Bystry River section (Bystre); for location see Figures 1 and 2; explanations as in Figure 5 
Table 1

The proportion of principal lithofacies in the total thickness of the sections of the Istebna Formation studied

\begin{tabular}{|l|r|r|c|c|}
\hline \multicolumn{1}{|c|}{ Lithofacies } & $\begin{array}{c}\text { Thickness } \\
{[\%]}\end{array}$ & $\begin{array}{c}\text { Frequency } \\
{[\%]}\end{array}$ & $\begin{array}{c}\text { Thickness range } \\
{[\mathrm{cm}]}\end{array}$ & $\begin{array}{c}\text { Average thickness } \\
{[\mathrm{cm}]}\end{array}$ \\
\hline S & 41.6 & 51.6 & $2 \div 750$ & 22 \\
\hline SG & 17.0 & 9.6 & $3 \div 560$ & 49 \\
\hline CS & 5.7 & 3.5 & $4 \div 480$ & 45 \\
\hline C & 2.0 & 0.8 & $5 \div 425$ & 63 \\
\hline$[\Sigma]$ S, SG, CS, C (S-C) & 66.3 & 65.6 & - & - \\
\hline M & 9.1 & 3.2 & $5 \div 1900$ & 78 \\
\hline MS & 7.8 & 15.7 & $1 \div 150$ & 14 \\
\hline SM & 3.5 & 14.1 & $1 \div 162$ & 7 \\
\hline MG & 12.3 & 1.0 & $30 \div 2450$ & 333 \\
\hline
\end{tabular}

tures, usually in the form of dish structures, appear in some beds of massive sandstone. The characteristic particulate elements of the S-C deposits are locally occurring exotic clasts of igneous, metamorphic and sedimentary rocks. These clasts can constitute predominant elements of the sediment framework, e.g., in exotic conglomerates (Fig. 3D) or oversized clasts, some exceeding several tens of centimetres, occurring in the top parts of certain beds. Exotic clasts are mainly represented by gneiss and crystalline slate, less often granitoid. Exotic lithoclasts of sedimentary rocks occur sporadically. When they do, dark cherts predominate and limestones are the exception (Strzeboński, 2005).

The occurrence of a sedimentary structure whose forms may resemble the shape of some Ammonoidea fossils (Fig. 4C) is also connected with massive S-C deposits. These ammonite-like structures are composed of almost identical material as the environment in which they occur, i.e., sandy or sandy-gravelly siliciclastic material, which is why it is very difficult to notice them. The diameter of the ammonite-shaped forms ranges from several to almost 30 centimetres. An important feature of this structure is a more or less developed spiral clockwise or counter-clockwise shape (right or left ammonite structure). Some forms also have a well-developed straight end-segment (Fig. 4C).

\section{EXPERIMENTAL MODELLING OF UNDERWATER SANDY FLOWS}

Experimental modelling was conducted in order to get a better understanding of the nature and behaviour of subaqueous sand flows. The modelling study was conducted on the basis of an approximate and simplified physical model of a subaqueous sand slope at the angle of repose. The model was an artificial basin with the size of $7 \times 7 \times 2 \mathrm{~m}$ formed on a sandy sea shore. The modelling study consisted in attempts to recapture the nature of transportation, potential transformations and deposition connected with sand flows. Moderately sorted siliciclastic sea shore sand was used in the experiment. The amount of clastic material used in the modelling ranged from one to several kilograms. The experiment consisted in repeating movements of sand, which was mechanically pushed down from the edge of the basin. After artificially forced initiation of non-cohesive granular mass movement, further flow of the clastic material on a slip slope (avalanche slope) occurred in a natural manner. The modelling study was demonstrative and descriptive and it was conducted without specialist instruments.

As the initial sample weight increased the sand flow grew longer in duration, but it did not exceed 10 seconds. During the natural flow down the slope, the clastic material took the form of an elongated tongue. The central part of a narrow tongue was more mobile whereas its thinner edges were clearly breaking, especially in the second phase of the movement (after the initial acceleration period). Distance with increased mass was also extended by up to approximately one metre. During the flow, a compact aggregate of non-cohesive particles of the sandy tongue partly moved and activated the material in the immediate vicinity of the tongue, and partly incorporated it in the flow. After the initial acceleration, the sand movement was rapidly slowed down and then suddenly stopped, which resulted in the formation of a tongue relief with a sharp head clearly outlined at the bottom. Each time the sand flow mass was frozen a short (lasting approximately one second) and small (approximately one centimetre in size) "cloud" of turbulent suspension appeared in the end section. The sand elevated in this way partly fell within the area of the flow end and it was partly thrown ("detached") and embedded slightly lower in sediments not associated with the flow. After deposition of the clastic material, current activity of clear water stirred by the flow was still visible. This current radially travelled along the bottom of the reservoir moving and dragging particles of shell and plant detritus. Movement of clear surrounding water also occurred earlier on the sides of the sandy tongue which was moving downslope in a compact manner. This could be observed as a result of the temporary elevation of plant detritus from the bottom and along the sides of the flow in the initial acceleration phase.

\section{SEDIMENTATION}

Siliciclastic sandy-to-gravelly sediments may be associated with a deep-water environment, stretching between the shelf edge and basin plain (see Shanmugam, 2006; Mulder, 2011). In the proximal slope area, slide, slump or avalanche mass movements may be frequently activated, chaotically (from different places and at different times) but linearly, along the edge of a shelf-margin overburdened with clastic material. Mass wasting could be largely generated by driven shelf-mar- 
gin deltas (Porębski and Steel, 2006) that reach the shelf edge or, in more a general sense, from the fronts of advancing shelf-embankments (sandy- and/or sandy-gravelly migrating mounds) into deep-water settings. Coherent slides during downslope motion may undergo fragmentation and relocation in rigid packages, preserving the form of "rigid" plugs among other, undisturbed deposits, but they usually transform into slumps with plastic deformations. A slumping mass which undergoes further fragmentation tends to undergo frontal liquidization (sensu Allen, 1984), and is thus diluted and accelerated during the downslope movement (see Wojewoda, 2008). As a result, the sliding or slumping mass, depending on the composition of its constituent material, most often evolvs into different types of homogeneous debris flows (cohesive or non-cohesive types) or grain flows. Clastic material may be quickly deposited by frictional freezing in the case of a non-cohesive granular mass. In the case of sediments rich in mud, their redeposited mass, particularly in muddy flows or muddy debris flows, may be hindered by cohesive strength or, due to dilution, incrementally transformed into turbidity current to varying degrees during further movement (see Unrug, 1963; Fisher, 1983; Shanmugam, 2006, 2012; Felix et al., 2009; Haughton et al., 2009; Mulder, 2011; Talling et al., 2012). Such a course of sedimentation may partly overlap with traction transport and by tractional deposition influenced or substantially affected by passing of bottom currents or turbidity currents. Moreover, hemipelagic sedimentation from suspension can also occur, which may ultimately lead to the formation of polygenetic complex (composite) beds (i.e., multiple and multifaceted depositional processes; e.g., Figs. 3G, 4F, 5 and 6). Local accumulations of mud during breaks in sandy-gravelly deposition (resedimentation) may frequently be the cause and at the same time the site of the slip/slide in the superimposed series, and thus contribute to the release of mass wasting and gravity flows. Sandy-gravelly debris flows generated this way become enriched in mud matrix and mudstone clasts. Due to the admixture of mud to the sandy-gravelly flows, at the right dilution and with dewatering and elutriation turbidity currents may be generated above debris flows. Sandy-gravelly bodies deposited on the distal part of a slope and at its base can be considerably elongated and linguoid with lenticular geometry in cross-section. Sometimes, after greater mass redeposition, more extensive debris sheets also formed. Individual detrital lithosomes underwent lateral and vertical coalescence and formed an apron covers built the apron depositional system (e.g., Reading and Richards, 1994; Strzeboński, 2009). Secondary elements of the apron architecture are the fillings of erosional wash-outs and of ephemeral chutes (e.g., Fig. 3F, H). The single (isolated) or multi-storey (superimposed) chutes were in the form of small erosional channels, which were unstable (vertically and laterally position change), and quickly filled up (cf., Janocko et al., 2013). Small-scale pseudo-lobe bodies sometimes formed at their outlets. Such sandy-gravelly bodies may have fan-like geometry, revealing a possibly thickening upwards pattern (negative sequences) but with a massive bed structure and without mudstone interbeds.

\section{PALAEOTRANSPORT DIRECTIONS}

The generalised pattern of palaeotransport directions of clastic material in particular lithostratigraphic divisions of the Flysch Carpathians was described in Ksią kiewicz (1962) and Ślączka (1986). It was shown that palaeotransport in the west- ern part of the Silesian Basin during sedimentation of the Istebna Formation (Late Cretaceous to Paleocene) was from the SW and W. These directions were interpreted to indicate sediment supply from the Silesian Cordillera situated to the south of the Silesian Basin, and a general inclination of the longer axis of the Silesian Basin to the east. These studies also proposed that palaeotransport from the NW was constrained by the topography of the basin bottom.

Transport directions of the clastic material were determined by the use of the following: scour-and-fill structures (axes of small erosional-depositional channels, chutes and wash-outs), flow lineation, thrust imbrication and cross-bedding - primarily in S-C deposits. Directional sole structures in small-scale (flute casts and tool marks), cross-laminations - mainly for MS and SM lithofacies - were also used. Directional structures observed in the sandstone-to-conglomerate debrites indicate palaeotransport (without corrections for the tectonic evolution of the Carpathian orogen, e.g., Rauch, 2013) from the S, SSW and SW to the N, NNE and NE (see Figs. 5 and 6), which supports the existence of a source area in the form of the Silesian Ridge (islands of the Silesian Ridge) providing clastic material to the southern facial zone of the western part of the Silesian Basin.

In other deposits, e.g., thin-bedded, fine-grained ripplemarked sandstones, other directions are observed - from $\mathrm{W}$ to E or even from NW to SE. The directions from the NW may be particularly connected with the limitation of the lateral spread of gravity flows (in the semi-graben of the Silesian Basin) by the Sub-Silesian elevation zone (a rebound effect) (see Ksia kiewicz, 1962; Unrug, 1963, 1968; Ślączka, 1986; Matyszkiewicz and Słomka, 1994; Ślączka et al., 2006). The direction from the W (parallel or at a slight angle to the long basin axis) may also represent contour currents (see Unrug, 1980).

\section{DISCUSSION}

Experimental observations of sandy flows may suggest that normally graded and thin-bedded (from several to over ten centimetres) sandstone depositional intervals, locally occurring in the tops of some thickly- and very thickly bedded massive deposits of sandstone-conglomerate lithofacies association (S-C), could originate from a short-term turbulent suspension (water and sand). This turbulent suspension may be induced on the top surface of a sandy-to-gravelly mass flow the moment it rapidly stopped. Such intervals with normally graded bedding may be genetically associated with the underlying deposits (the result of a single sedimentary event) or they may cover deposits accumulated earlier with which they have no genetic connection (separate events). The second case of settling the normally graded sand on the top surface of deposits of a previous flow is associated with the "detachment" of a turbulent suspension and exceeding the range (head) of the mass flow from which it emerged. However, due to subaqueous erosion commonly linked with sandy-to-gravelly flows, intervals of turbulent suspension (sandy turbidite) which may primarily occur are not usually preserved in section and their material was incorporated in the subsequent flow as fragments of layers or as single grains. So as a result of the lack of a rock record of potential turbulence intervals in most cases, it is difficult to state whether or not the transformation and initiation of turbulence from a sandyto-gravelly flow occurred each time. In the case of a preserved turbidite it is often difficult to determine (typically due to amalgamation) whether it is a syngenetic or epigenetic turbidite in relation to the lower bed (the same sedimentary event and trans- 
formation or separate events). Moreover, since the sandy turbulence episode would have been very short (poor muddy matrix) and it would have occurred above the sandy or sandy-gravelly and not the mudstone bottom, turbulence would not have developed typical flute casts and those which emerged would have had only a small chance to be consolidated in the incoherent sandy-gravely material. Moreover, the small-scale postdepositional traction transport (observed during the experimental modelling), occurring as a result of clear water secondary currents generated by the flow head shock wave, was also likely to occur during these processes in the natural environment. Different lamination types could have formed as a result of sediment reworking conducted by tractional bottom currents in relation to their flow regime. This process may suggest that laminated sandstones associated with the S-C deposits originated as a result of tractional activity not associated with typical long-term muddy-sandy turbidity currents.

According to Talling et al. (2012), massive clean sandstone can potentially be created by different types of subaqueous sediment density flows, i.e., both turbidity currents and debris flows, although they stress that such sandstones are difficult to distinguish and their origins are as yet not well-established. The first way they are created is through deposition by a high-density turbidity current forming a clean turbidite sandstone (progressive deposition incrementally in a layer-by-layer pattern, a traction carpet, damped turbulence at concentrations even of 10-35 vol.\% and strongly hindered settling; similar to the Ta interval of the Bouma sequence, Bouma, 1962; see also Lowe, 1982). The second option (with a similar meaning considered by Lowe, 1982) is the deposition of massive clean sandstone in an en masse style by a poorly-cohesive liquefied debris flow (high sediment concentration flow). Similar but non-cohesive type liquefied debris flows (laminar plugs) are also responsible for en masse deposition (settling through abrupt freezing) of predominantly ungraded clean debrite sandstones with a swirly texture (swirly fabric). Such a patchy texture, related to postdepositional partial liquefaction (static settling during in situ consolidation) and soft sediment contortion (deformed patches of different grain sizes forming patchy grading), may be the best diagnostic feature of sandstone debrites elsewhere. Furthermore, randomly scattered clasts are regarded as the main features of some debrites, whereas clasts constituting distinct horizons are a distinctive feature of some high-density turbidites (according to Talling et al., 2012).

Field observations show that many of the individualized clastic bodies in the Istebna Formation, formed by deposits of the $\mathrm{S}-\mathrm{C}$, only seemingly represent sediments of single depositional events (e.g., Figs. 3A, F, 5 and 6). In fact, such units are amalgamated (complex beds) and show features indicative of deposition by several separate events. Furthermore, the occurrence of different depositional intervals within one bed (complex bed) may suggest transformations and/or conversions from one type of gravity-driven process into another but with different physical properties (multifaceted processes) (e.g., Unrug, 1963; Middleton and Hampton, 1973; Shanmugam, 2006. 2012; Wojewoda, 2008; Felix et al., 2009; Mulder, 2011; Talling et al., 2012) or amalgamated deposits of separate sedimentary events and/or a mix of these.

An intuitive attempt to combine and use one term defining a complex bed, for instance, a fluxoturbidite (e.g., Dzulynski et al., 1959; Leszczyński, 1989) or relating it to a sedimentary series of deposits of a different origin (i.e., interbedded debrites and true turbidites), e.g., a fluxoturbidite sequence (Unrug, 1963) or hybrid sediment gravity flow deposit (hybrid event deposit, Haughton et al., 2009) could be justified under certain conditions. For example, if the complex deposit was the result of a single sedimentary event during which there was the activity of various gravity-driven processes (possible transformations; e.g., from a sandy-gravelly debris flow to a turbidity current), one might call such a unit a fluxoturbidite (in a general and descriptive sense). From this point of view, a fluxoturbidite may be considered a complex deposit comprised both of sandstoneconglomerate debrite and turbidite (debrite-turbidite couple). However, in a number of cases we can observe a thick series of complex beds or single beds exclusively composed of massive sandstone-to-conglomerate deposits (sandy-to-gravelly debris flow deposits). If this is the case, expressions such as sandstone-, sandstone-conglomerate debrite and sandstone- or sandstone-conglomerate debrite series seem to be more suitable than the term fluxoturbidite, because of the absence of any kind of turbidites (sensu Sanders, 1965; see also Hsü, 2004).

The overlapping of different contemporaneous depositional processes associated with separate sedimentary events or their subsequent occurrence at relatively short time intervals is also possible. This is clearly visible in sedimentary bodies composed of amalgamated deposits of different lithofacies. In the case of thick bodies composed of one type of relatively homogeneous lithofacies and the lack of clear amalgamation surfaces, it is difficult to distinguish separate depositional intervals (see Figs. 3A, F, G, 5 and 6). This complicates the full interpretation of their sedimentary origin. Such a discrete genesis can be the cause of incorrect interpretations both at the level of sedimentary structures (e.g., two amalgamated beds of massive coarse- and fine-grained sandstone could be interpreted as one bed of normally graded sandstone) and regarding the type of sedimentation processes, respectively. In addition, some fracture surfaces (e.g., oblique joints) in tectonically disturbed massive deposits, can be mistakenly interpreted as sedimentary surfaces (bedding planes).

Normally graded sandstone deposits usually fine- (less often medium-) to very fine-grained, preferably thin- to very thinbedded which have a sharp erosional base typically with flute casts (in cases where they overlap mudstone deposits) represent turbidites, corresponding to the Ta division of the Bouma sequence (see, e.g., Fig. 3B).

Ripple cross-laminated sandstones, as interpreted for instance by Bouma (1962), can result from incremental settling of particles from a turbidity current (Tc member of the Bouma sequence; e.g., Mulder et al., 2008; Mulder, 2011) or from bedload reworking in the lower flow regime (e.g., Talling et al., 2012). However, ripple cross-laminated sandstones, as well as their flat-parallel and wavy-laminated counterparts, can also be interpreted as bedforms widely influenced or substantially affected by bottom currents of various origins (in a broad sense, Rebesco et al., 2008). These structures are subject to significant force, for instance, by tractional currents (e.g., Allen, 1984; Martín-Chivelet et al., 2008; Shanmugam, 2008, 2012). They can also be formed by tractional bottom currents of "clear" water generated by the passage of a turbulent suspension over bottom sediments (see Unrug, 1977, 1980). Some such distinctly laminated deposits are also considered to be deposits of contour currents (i.e., a special case of bottom currents), traditionally called contourites (e.g., Unrug, 1980; Hsü, 2008; Hüneke and Stow, 2008; MartínChivelet et al., 2008; Shanmugam, 2008, 2012).

The occurrence of oversized exotic clasts in the top parts of sandstone-to-conglomerate debrites demonstrates the quasi- 
plastic behaviour and pseudo-laminar flow state of the sandyto-gravelly debris flows (flow strength and buoyant lift). Apart from this, it indicates the erosion of older sediments in the uplifted and emergent area of the basin which once again became part of the source area (see Matyszkiewicz and Słomka, 1994). Reworking of older deposits resulted in the possibility of a secondary occurrence of exotics in the newly developed sediments. In the case of crystalline exotic rocks, it may also suggest the erosion of parent rocks in the source area (see e.g., Unrug, 1968). Intensified sandy-gravelly deposition/redeposition in the Silesian Basin in the Late Cretaceous (Campanian-Maastrichtian) period, recorded with a sedimentation rate exceeding the estimated hundred metres per million years (e.g., Lower Istebna Sandstone deposits; see Fig. 1), could exceed the rate of basin subsidence and lead to a considerable shallowing of the proximal part of the basin slope.

Increased mass sedimentation in the Silesian Basin during the Late Cretaceous and Paleocene was significantly influenced by intense denudation of the elevated source area - the Silesian cordillera (see also Ksią kiewicz, 1962; Unrug, 1963, 1968; Ślączka, 1986; Słomka, 1995; Poprawa et al., 2002, 2004; Golonka et al., 2008). The uplift of the source area was connected with processes of tectonic reconstruction in their surroundings (e.g., Pescatore and Ślączka, 1984; Oszczypko, 1999; Nemčok et al., 2001; Olszewska and Wieczorek, 2001; Poprawa et al., 2002; Golonka, 2004; Cieszkowski et al., 2012; Ślączka et al., 2012; Rauch, 2013). During decreased diastrophic movements, the peneplanated source area did not provide coarse-clastic terrigenous material (regolith in a genetic sense) to the basin and even the process of eustatic regression would not be able to deliver a considerable amount of sand and gravel from an "empty" shelf. But with the strongly eroded source area (during intense diastrophic activity) even an eustatic transgression would not constrain mass redeposition from the overburdened, clastic shelf. Therefore the eustatic factor, even though ancillary or limiting the development of coarseclastic mass sedimentation/resedimentation to a deep-water setting, does not seem to be of primary importance.

Sediment gravity-driven processes such as sandy-to-gravelly debris flows have the capacity to transport even outsized clasts (projecting clasts at the tops of some sandstone-conglomerate debrites). An impediment to the long-term and longdistance lateral spread of the en masse transported material is its grain size composition and frequently of a low content of muddy matrix (i.e., from <1 to 25 vol.\%; Unrug, 1963; Shanmugam, 2006), which causes relatively quick deposition through frictional freezing. Increase in transport distance may occur as a result of frontal liquidization of the slump and acceleration of the movement of the liquidized mass (see Wojewoda, 2008). The consequence is flow deconcentration caused by assimilation of ambient fluids, aquaplaning and intergranular flow upwards. In such cases, what may occur is not only the evolving of slides/slumps into debris flows but also transformations directly into turbidity currents or of debris flows into turbidity currents (see Unrug, 1963; Fisher, 1983; Shanmugam, 2006; Felix et al., 2009; Mulder, 2011). Preservation of submarine sandygravelly slumps as synsedimentary folds, ruptured to different degrees, among other non-deformed deposits, is usually limited. Typically, slumps are not "frozen" but evolve into sandygravelly debris flows, in which almost complete decoherence and homogenizing of the transported non-cohesive granular mass is observed. A low mud matrix content in "clean" sandy- gravelly debris flows can be explained, e.g., by elutriation, i.e., the washing away of clay and silt-sized particles during flow transformation into a turbidity current (see Fisher, 1983).

Dish structures and other dewatering structures may indicate aquaplaning (hydroplaning; see Shanmugam, 2006), e.g., during the relatively rapid movement of sandy debris flow on a relatively steep slope (near the angle of repose) or may represent the post-depositional consolidation phase (in situ) of "fresh" sediment (e.g., Talling, 2012). Such a flow is less permeable to water in comparison with, e.g., sandy-gravelly debris flows.

Due to different sedimentary processes acting in sandyto-gravelly debris flows, depositional intervals with different sedimentary structures in sandstone-to-conglomerate debrites can be observed (e.g., dish structures, massive structure, inverseand/or inverse-to-normal grading).

Small-scale lobe-like sediment bodies with negative sequences of beds (showing a thickening upwards pattern) lacking mudstone interbeds, formed by sandy-gravelly debris flows at the mouth of small, ephemeral channels, cannot be compared with large-scale lobes constituting deep-sea fan systems.

The MG lithofacies (gravelly mudstone, Fig. 2) can be interpreted as muddy debris flow deposits (e.g., Shanmugam, 2006) or can also be referred to as olistostrome deposits (containing olistoliths, chaotically scattered in the muddy-sandy matrix; see e.g., Flores, 1959; Abbate et al., 1970; Jankowski, 2007; Cieszkowski et al., 2009, 2012; Ślączka et al., 2012).

A different lithofacies category is represented by synsedimentarily deformed/disturbed deposits (SDD; see e.g., Ghibaudo, 1992; Słomka, 1995; Strzeboński, 2005). This genetic lithofacies consists of varied rock types involved in common deformation structures (different degrees of folding, crumpling and ripping) observed at the scale of field exposures between undisturbed deposits. The SDD units range in thickness from 1 to $7 \mathrm{~m}$ and the mean thickness is $\sim 3 \mathrm{~m}$. The SSD lithofacies constitute $0.9 \%$ of the Istebna Formation.

The greatest thickness of the S-C deposits in the Istebna Formation recorded in the Beskid Śląski Mts., indicates that exactly this area represented the basin depocentre during their accumulation. The depocentre was linked with the greatest uplift of one of the Silesian Ridge fragments. That fragment (segment), which was the Silesian island block was responsible for the greatest supply to the Silesian Basin.

Ammonite-shaped (at times resembling some Ammonoidea fossils) vortical sedimentary structure (Fig. 4C) observed in S-C deposits may have formed as a result of secondary swirls of "clear" water which occur during mass and highly energetic sandy-gravelly debris flows. This kind of structure may be formed especially during turbulence generated at the sides of tongues of such flows. Their distinct clockwise or counter-clockwise spiral structure (right or left ammonite structure) may correspond with the back-turbulence which may occur on the left and on the right side of the elongated masses moving down the slope. The spiral shape may result from the vortical water movement that sucks in and twists detrital material, presumably in a similar way to the vortexes formed by the paddles of a rowing boat. A straight end-segment preserved in some spiral forms may indicate the final turbulence direction prior to the deposition as the sediment transportation capacity decreases. Since this direction is close to the overall palaeotransport direction in sandy-gravelly debris flows, it may be considered an azimuth directional feature. 


\section{SUMMARY}

The types of sediment gravity-driven flows and their related sedimentary processes, triggering mechanisms, methods of transport and deposition of clastic material, possible transformations and conversions, which result in rock features, mostly depend on the following: initial weight, released energy, seabed topography and velocity conditions; grain-size distribution and sorting; shape, rounding of grainsand their specific weight, as well as the concentration of particles in the sediment-water mixture (variable flow density).

Even though the conditions used in the subaqueous sand flow experimental modelling were approximate and the size of physical model was insubstantial, it was possible to obtain replicas very similar to the original. The experimental sand flows, small-scale as they were, imitated the course of natural processes in a relatively representative manner. Observation of reproduced sand flows undoubtedly revealed their properties to some extent, which enabled a better grasp of the complex nature and behaviour of such gravity flows in natural systems. Hence, the results of the sand flows modelling study to some extent gave the possibility to experimentally constrain certain assumptions and to draw more general conclusions used at the interpretation stage of this work.

According to Bouma (1962), distinctly laminated deposits (e.g., ripple cross-laminated, flat-parallel and wavy-laminated sandstones) can result from turbidity currents ( $\mathrm{Tb}, \mathrm{Tc}$ and $\mathrm{Td}$ vertical divisions of the Bouma sequence; see also, e.g., Mulder et al., 2008; Mulder, 2011). Talling et al. (2012) in turn suggested that cross-lamination can be formed by bedload reworking, while Unrug (1977, 1980), Allen (1984), Hsü (2008), Hüneke and Stow (2008), Martín-Chivelet et al. (2008) and Shanmugam $(2008,2012)$ also indicated the possibility of forming such laminated structures by the action of traction bottom currents. In addition, various types of laminated sediments with a combination of traction structures can be commonly formed in deep-water environments under the influence of "clear" water bottom currents (e.g., Unrug, 1977, 1980; Allen, 1984; MartínChivelet et al., 2008; Shanmugam, 2008, 2012).

For example, cross-lamination of distinct ripple bedforms may represent reworking (erosion, then transport, sorting and finally accumulation) of pre-existing sediments of seabed surfaces both during and after their deposition (bottom-current tractional activity). Thin layers of laminated sandstones, in particular ripple cross-laminated, accompanied by thick-bedded and massive deposits of sandstone-conglomerate lithofacies association (S-C), can be interpreted as bottom-current-reworked deposits (bottom current tractionites). Even if these laminae are only partially preserved they may also be indicative of intermissions between sandy-to-gravelly debris flows.

In sections dominated by siliciclastic deposits of the sandstone-conglomerate lithofacies association (sandstone-to-conglomerate deep-water debrites) one can observe typical features which can be interpreted in the following manner (mainly after, e.g., Unrug, 1963; Allen, 1984; Shanmugam, 2006 and by the author's observations):

- massive structure (no size-grading or lamination) when occurring in matrix-supported and poorly sorted deposits: deposition by non-cohesive sandy- or sandy gravelly- or gravelly sandy- or gravelly debris flows (non-Newtonian laminar flows with a flow strength and mass deposition due to flow frictional freezing), deposits forming elongated, high relief slope-apron sheets (apron covers); or in the cases of clast-supported and well-sorted deposits: sedimentation by grain flows (gravelly- or sandy flows dominated by collisions between individual particles) tend to be more narrow tongues, deposits as clast-supported conglomerates (with a poor sandy matrix) or well-sorted sandstones (clean, without muddy matrix);

- vertical, sudden changes in grain size, with the lack of a clear bounding surface: amalgamation of beds deposited by separate sandy-to-gravelly debris flows or change (sudden drops) in flow velocity;

- randomly scattered quartz gravel supported by a sandy matrix: deposition by sandy gravelly- and gravelly sandy debris flows with significant flow strength;

- "floating" mudstone clasts (random- and/or planar clast fabric): deposition by sandy- or sandy gravelly- or gravelly sandy debris flows (flow strength and buoyancy);

- rafted mudstone clasts near the top of bed: deposition by sandy- or sandy gravelly- or gravelly sandy debris flows (flow strength and buoyant lift);

- outsized clasts near the top of the bed: deposition by sandy- or sandy gravelly- or gravelly sandy debris flows (flow strength and buoyant lift):

- inverse-to-normal grading: deposition by sandy gravellyor gravelly sandy debris flows (flow strength, laminar state, hindered settling) and/or change in flow velocity and/or transformation of debris flow into turbidity currents and/or gravity sieving (dropping of smaller grains between greater clasts);

- lenticular layers (in cross-section) with sharp lower and upper contacts: sandy- or sandy gravelly- or gravelly sandy debris flows (flow strength, laminar state, depositional freezing);

- single layer of gravel grains at the top surface of bed: lag deposits (washing of previous coarse-grained sediments, deposition from traction bedload);

- armoured mudstone clasts and armoured mudstone balls at the top of the bed: deposition by sandy- or sandy gravelly- or gravelly sandy debris flows (flow strength and buoyancy, frictional freezing);

- erosional pockets (different scales) with massive or normally graded fills: deposition by sandy- or sandy gravelly- or gravelly sandy debris flows (freezing or hindered settling); fills of wash-outs or small erosional-depositional channels (chutes). In the case of a "clean" clast-supported conglomerates at the base of scour-and-fill structures: possible channel lag (rewashed deposit, smaller particles washed out);

- contorted/disturbed sandstone beds between undisturbed units, the original bedding is largely destroyed (different degrees of folding, crumpling and ripping), synsedimentarily deformed deposits: deposition by slumping;

- flat-parallel-, wavy- and/or ripple-lamination: deposition by tractional settling beneath the passing of turbidity currents and also as a result of sediment reworking under the influence of clean-water bottom-currents; deposits: tractionites (especially bottom-current reworked tractionites) and uniquely contourites (if they are products of contour currents);

- continuous lateral changes in grain-size: the result of changes in the distribution of the flow speed (greater in the centre and smaller on the periphery);

- lateral discontinuity in grain-size and of beds: erosional or depositional pinch out of beds;

- cross-bedding on a large-scale: filling or overlying minor irregularities in the seabed depositional surface (depressions or elevations) by bottom currents (tractional settling), may also be associated with large-scale bedforms (large-scale ripples, sandy waves); 
- dish structure: result from both syn- or post-depositional (in situ) sand liquidization (liquefaction and/or fluidization) and hydroplaning in sandy debris flows, due to ascending pore fluid (water-ascent structure).

- only simple (single) normal grading in sandstone and/or mudstone beds (for details see the glossary and discussion): deposition by waning turbidity current (Newtonian flow without strength), incremental, gradual settling (aggradational continuum) from a fully turbulent suspension; deposits: sandstoneand mudstone turbidites.

A deep-water individual sedimentary event may contain either one only kind of gravity-driven process (essentially) or several different ones (multiple and/or multifaceted sedimentary processes) linked during evolution (i.e., from initiation, through the transportation phase and possible transformations and/or conversions from one process type to another and to the depositional phase with final consolidation). In the case of a composite origin of such an event, the geological record may be more or less precisely reflected in the preserved composite deposit (complex bed). Such a deep-water single sedimentary event (pulse) comprising at least two different but interrelated sediment gravity driven flows, for example, a sandy-gravelly debris flow (plastic rheology and laminar behaviour) and a turbidity current (fluidal rheology and turbulent behaviour) is also referred to as a hybrid flow (hybrid sediment gravity flow; Haughton et al., 2009) or a hybrid event of subaqueous sediment density flow (Talling et al., 2012). An individual sedimentary body (unit of a single event) containing both sandstone-to-conglomerate debrite and turbidite is also referred to as a hybrid event bed (hybrid sediment gravity flow deposit, Haughton et al., 2009) or "linked turbidite-debrite bed" (Talling et al., 2012).

The sedimentary boundaries (bedding planes) of beds deposited by single sandy-to-gravelly debris flows in deep-water settings are usually obscure. Their obscurity frequently results from widespread erosion and the common amalgamation of beds of a similar mineralogical and granulometric composition. What favours single layer recognition is weathering (e.g., Fig. $3 G)$, which often highlights the irregular profile of pinching out layers and also an abrupt change in grain-size.

The following elements observed in the Istebna Formation deposits indicate that the basic depositional system of the S-C deposits was linearly supplied a deep-water slope apron with mass sedimentation of a chaotic type (see the models of apron systems rich in sand and gravelly material; Reading and Richards, 1994; see also Strzeboński, 2009): there is a dominant lack of organised changes in the grain-size distribution or thickness of subsequent layers in the profiles (Figs. 5 and 6); a lack of typically developed depositional lobes and their outer zones (lobe fringes and fan fringes; see e.g., Mutti and Ricci Lucchi, 1972); a linear mode of delivery of the detrital material (as opposed to "punctual" with a radial distribution); a tongue-like shape of elongated lithosomes with lenticular cross-section geometry, underwent lateral and vertical coalescence and forming high relief sheets (clastic covers); a domination by sandstoneconglomerate siliciclastic debrites (Figs. 4E, F, 5 and 6) with a scarcity of directional current structures (especially e.g., flute casts); the occurrence of mudstone debrites and synsedimentary deformed deposits (see Strzeboński, 2005).

"Ordered" series of clastic deposits (e.g., "positive" depositional sequences) of a relatively small thickness (limited to several metres) and showing a decreasing bed thickness and grain size upwards were observed in the succession. There were also cases of single coarse-clastic fills (conglomerate or sandy conglomerate) of clearly erosional pockets (scour and fill structures) in places graded normally. These structures indicate the occurrence of wash-outs and ephemeral chutes (small channels) in the apron sheets (Figs. 3F, H, 5 and 6).

To a great extent mass movements may be generated at the fronts of driven shelf-margin deltas (Porębski and Steel, 2006) or, in a more general sense, from progradational shelfembankment systems (sandy- and/or sandy-gravelly advancing mounds) exceeding the shelf edge.

The accurate interpretation of the deep-water siliciclastic depositional system is also of key importance in oil exploration (Shanmugam, 2006). Considering future exploration, it is crucial to define:

- whether research is conducted within the apron sheet (slope-apron depositional system, sensu Reading and Richards, 1994),

- or within depositional lobes (fan system of basin floor; sensu Mutti and Ricci Lucchi, 1972).

In the first case (with an assumed model rich in sand and gravelly material), tongue-like bodies undergo coalescence, composed of $\mathrm{S}-\mathrm{C}$ deposits often form units with a substantial thickness (up to several tens of metres) without mudstone interbeds (Figs. 5 and 6) and thus make good, inter-communicated reservoirs. However, the correlation of such sections even over distances of several tens of metres may be difficult or even impossible. This results from the elongated tongue-like patterns of distribution of sandy-gravelly debris flows and the pinching out of their bodies. Moreover the occurrence of lensoid channel-filling bodies (Figs. 5 and 6) and/or muddy debris flow deposits (sometimes of the olistostrome type; see Strzeboński, 2005,2009 ) and/or local turbidites or mudstones of different origin can cause additional problems with correlation, and more importantly, contribute to the occurrence of unwanted permeability barriers. If the second interpretation model is chosen, it is necessary to consider the radial fan lobes of submarine fans which consist of normally graded sandstone turbidites interbedded with mudstones, frequently forming negative sequences many metres thick with beds well-correlatable over long distances.

In order to differentiate their origin from other types of sandstones and conglomerates, the S-C deposits commonly occurring in the succession (Figs. 5 and 6) without interbedding of other types of deposits, especially without lithofacies M, MS and SM (see Fig. 3B), can be also referred to as an association of sandstone-conglomerate debrites (D-S-C), generally understood as linked deposits formed from sandy-to-gravelly debris flows. Whereas deposits of a single type of lithofacies/depositional interval can be termed as follows:

- sandstone debrite - in the case of sandstone (usually poorly sorted and massive) interpreted as a sandy debris flow deposit (see Shanmugam, 2006);

- gravelly sandstone debrite - in the case of gravelly sandstone considered to be sandy gravelly debris flow deposit;

- sandy conglomerate debrite - sandy conglomerate interpreted as a gravelly sandy debris flow deposit; 
- conglomerate debrite - conglomerate especially ungraded with the participation of a poorly sorted sandy matrix considered to be gravelly debris flow deposits.

In the case of "clean" conglomerate with a clast-supported fabric and very poor matrix, one observes the grain flow type. Because such grain flows typically occur as grain avalanching (i.e., gravelly avalanches) on steep slopes, where the angle of repose is most likely exceeded (Unrug, 1963; Stow et al., 1996), their avalanche units at different scales can be called conglomerate avalanchite. Meanwhile, "clean" and well-sorted sandstone, which can be recognized as grain flow deposit (sandy "avalanche" deposit), can be termed sandstone avalanchite. Yet another origin of the "clean" conglomerate can be suggested for the deposit which constitutes the lowest part of the channel-fill. It is possible that such accumulation results from "washing" typical of a river channel lag and can be considered as a type of channel lag deposit. On the other hand, a single thin accumulation of tightly packed gravel grains spread laterally on the top surface of a sandstone-to-conglomerate bed is considered to be a lag deposit (pavement in general terms) and may indicate a sedimentary boundary between beds of consecutive mass flow pulses. Gravelly mudstone typical of deep-water slope-apron settings is sometimes seen to occur randomly in a succession between sandstone-conglomerate debrites
(Fig. 2). Such deposits can be interpreted as muddy debris flow deposits accumulated by sudden freezing of a cohesive flow of a muddy-sandy mixture with dispersed debris of gravel in its various widely understood forms (granules, pebbles, cobbles and boulders; see Strzeboński, 2005). This deposit can be defined generally as a mudstone debrite (DMG).

The results of the analyses of the palaeotransport directions of sandy-gravelly as well as muddy-sandy-gravelly detrital material, including the exotic clasts, point to the one of blocks of the Silesian Ridge as the source area of the deposits studied (see also Ksią kiewicz, 1962; Unrug, 1963, 1968; Ślączka, 1986; Słomka, 1995; Poprawa et al., 2002, 2004; Golonka et al., 2008).

Acknowledgements. The author is greatly indebted to the reviewers: in particular, to S. Leszczyński and also J. Janočko and P. Skupien as well as to the editors: T. Peryt and M. Krobicki - for their perceptive comments, valuable suggestions and linguistic support, which helped to improve the manuscript considerably. The study was financially supported by statutory research: AGH University of Science and Technology; Faculty of Geology, Geophysics and Environmental Protection; Department of General Geology and Geotourism; grant no. 11.11.140.173.

\section{REFERENCES}

Allen, J.R.L., 1984. Sedimentary Structures: their Character and Physical Basis. Elsevier, Amsterdam.

Abbate, E., Bortolotti, V., Passerini, P., 1970. Olistostromes and olistoliths. Sedimentary Geology, 4: 521-557.

Bouma, A.H., 1962. Sedimentology of Some Flysch Deposits: a Graphic Approach to Facies Interpretation. Elsevier, Amsterdam.

Burtan, J., 1972. Szczegółowa mapa geologiczna Polski, skala 1:50 000, arkusz Wisła (1028) (in Polish). Wyd. Geol., Warszawa.

Burtan, J., 1973. Objaśnienia do szczegółowej mapy geologicznej Polski, 1:50 000, arkusz Wisła (1028): 1-37 (in Polish). Wyd. Geol., Warszawa.

Burtan, J., Sokołowski, S., Sikora, W., ytko, K., 1956 Szczegółowa mapa geologiczna Polski, skala 1:50 000, arkusz Milówka (M34-87A) (in Polish). Wyd. Geol., Warszawa.

Burtan, J., Chowaniec, J., Golonka, J., 1984. Preliminary results of studies on exotic carbonate rocks in the western part of the Polish Flysch Carpathians (in Polish with English summary). Biuletyn Instytutu Geologicznego, 346: 147-159.

Burtanówna, J., 1936. Stratigraphie der Schlesischen Beskiden. Bulletin International de I'Académie Polonaise. Sprawozdania Polskiej Akademii Umiejętności, 41: 195-209.

Burtanówna, J., Konior, K., Ksia kiewicz, M., 1937. Carte géologique des Karpates de Silésie (in Polish with French summary). Polska Akademia Umiejętności: 1-104. Wyd. Śląskie, Kraków.

Campbell, C.V., 1967. Lamina, laminaset, bed and bedset. Sedimentology, 8: 7-26.

Cieszkowski, M., Golonka, J., Krobicki, M., Ślączka, A. Waśkowska, A., Wendorff, M., 2009. Olistoliths within the Silesian Series and their connections with evolutionary stages of the Silesian Basin (in Polish with English summary). Geologia, 35: 23-29.
Cieszkowski, M., Golonka, J., Ślączka, A., Waśkowska, A., 2012. Role of the olistostromes and olistoliths in tectonostratigraphic evolution of the Silesian Basin in the Outer West Carpathians. Tectonophysics, 568-569: 248-265.

Cohen, K.M., Finney, S., Gibbard, P.L., 2013. Internationa Chronostratigraphic Chart. ICS, January 2013, http://www.stratigraphy.org/ICSchart/ChronostratChart2013-01.pdf

Crowell, J.C., 1957. Origin of pebbly mudstones. GSA Bulletin, 68: 993-1010.

Dott, R.H., Jr., 1963. Dynamics of subaqueous gravity depositional processes. AAPG Bulletin, 47: 104-128.

Duranti, D., Hurst, A., 2004. Fludization and injection in the deep-water sandstones of the Eocene Alba Formation (U.K North Sea). Sedimentology, 51: 503-529.

Dzulynski, S., Ksią kiewicz, M., Kuenen, P.H., 1959. Turbidites in flysch of the Polish Carpathians Mountains. GSA Bulletin, 70: 1089-1118.

D ułyński, S., Radomski, A., 1955. Origin of groove casts in light of turbidity current hypothesis (in Polish with English summary). Acta Geologica Polonica, 5: 47-66.

Eliáš, M., 1970. Lithology and sedimentology of the Silesian unit in the Moravo-Silesian Beskydy Mts. (in Czech with English summary). Sbornik Geologickych Věd, Geologie, 8: 7-99.

Elverhoi, A., Norem, H., Anderson, E.S., Dowdeswell, J.A., Fossen, I., Haflidason, H., Kenyon, N.H., Laberg, J.S., King, E.L., Sejrup, H.P., Solheim, A., Vorren, T., 1997. On the origin and flow behavior of submarine slides on deep-sea fans along the Norwegian-Barents Sea continental margin. Geo-Marine Letters, 17: 119-125.

Felix, M., Leszczyński, S., Ślączka, A., Uchman, A., Amy, L., Peakall, J., 2009. Field expressions of the transformation of debris flows into turbidity currents, with examples from the Polish Carpathians and the French Maritime Alps. Marine and Petroleum Geology, 26: 2011-2020. 
Fisher, R.V., 1983. Flow transformations in sediment gravity flows. Geology, 11: 273-274.

Flores, G., 1959. Evidence of slump phenomena (Olistostromes) in areas of hydrocarbon exploration in Sicily. Proceedings 5th World Petroleum Congress, Sect. 1, pap., 13: 259-275.

Gani, M.R., 2004. From turbid to lucid: a straightforward approach to sediment gravity flows and their deposits. Sedimentary Record, 3: 4-8.

Gardner, J.V., Bohannon, R.G., Field, M.E., Masson, D.G., 1996. The morphology, processes, and evolution of Monterey Fan: a revisit. In: Geology of the United States' Sea Floor: the View from GLORIA (eds. J.V. Gardner, M.E. Field and D.C. Twichell): 193-220. Cambridge University Press, New York.

Gardner, J.V., Mayer, L.A., Hughes Clarke, J.E., 2000. Morphology and processes in Lake Tahoe (California-Nevada). GSA Bulletin, 112: 736-746.

Geroch, S., 1960. Microfaunal assemblages from the Cretaceous and Paleogene Silesian Unit in the Beskid Śląski Mts (in Polish with English summary). Biuletyn Instytutu Geologicznego, 153 7-138.

Ghibaudo, G., 1992. Subaqueous sediment gravity flow deposits: practical criteria for their field description and classification. Sedimentology, 39: 423-454.

Golonka, J., 2004. Plate tectonic evolution of the southern margin of Eurasia in the Mesozoic and Cenozoic. Tectonophysics, 381: 235-273.

Golonka, J., Waśkowska-Oliwa, A., 2007. Stratigraphy of the Polish Flysch Carpathians between Bielsko-Biała and Nowy Targ (in Polish with English summary). Geologia, 33: 5-28.

Golonka, J., Krobicki, M., Waśkowska-Oliwa, A., Vašíček, Z. Skupien, P., 2008. Main paleogeographical elements of the West Outer Carpathians during Late Jurassic and Early Cretaceous times (in Polish with English summary). Geologia, 34: 61-72.

Grzebyk, J., Leszczyński, S., 2006. New data on heavy minerals from the Upper Cretaceous-Paleogene flysch of the Beskid Śląski Mts. (Polish Carpathians). Geological Quarterly, 50 (2): 265-280.

Haughton, P., Davis, Ch., McCaffrey, W., Barker, S., 2009. Hybrid sediment gravity flow deposits - classification, origin and significance. Marine and Petroleum Geology, 26: 1900-1918.

Hohenegger, L., 1861. Die geognostischen Verhältnisse der Nordkarpathen in Schlesien und den angrenzenden Theilen von Mähren und Galizien. Perthes, Gotha, Wien.

Hsü, K.J., 2004. Physics of Sedimentology. Springer.

Hsü, K.J., 2008. Personal reminiscences on the history of contourites. Developments in Sedimentology, 60: 11-17.

Hüneke, H., Stow, D.A.V., 2008. Identification of ancient contourites: problems and palaeoceanographic significance. Developments in Sedimentology, 60: 323-344.

Jankowski, L., 2007. Chaotic complexes in Gorlice region (Polish outer Carpathians) (in Polish with English summary). Biuletyn Państwowego Instytutu Geologicznego, 426: 27-52.

Janocko, M., Nemec, W., Henriksen, S., Warchoł, M., 2013. The diversity of deep-water sinuous channel belts and slope valley-fill complexes. Marine and Petroleum Geology, 41: 7-34.

Klaucke, I., Masson, D.G., Kenyon, N.H., Gardner, J.V., 2004. Sedimentary processes of the lower Monterey Fan channel and channel-mouth lobe. Marine Geology, 206: 181-198.

Kotlarczyk, J., Krawczyk, A.J., Leśniak, T., Słomka, T., 1997. Geologiczna baza danych GeoKarpaty dla polskich Karpat fliszowych (in Polish). Wyd. własne AGH, WGGiOŚ, Kraków.

Ksią kiewicz, M., 1953. Karpaty fliszowe między Olzą a Dunajcem (in Polish). In: Regionalna geologia Polski, t. 1, Karpaty, z. 2 : 305-361. Tektonika. Polskie Towarzystwo Geologiczne, Kraków.

Ksią kiewicz, M., ed., 1962. Geological Atlas of Poland. Stratigraphic and facial problems. Fascicle $13-$ Cretaceous and Tertiary in the Polish External Carpathians, 1:600,000. Państwowy Instytut Geologiczny, Warszawa.
Ksią kiewicz, M., 1972. Tektonika Beskidów (in Polish). In: Budowa geologiczna Polski, t. 4, Tektonika, z. 3, Karpaty (in Polish). Państwowy Instytut Geologiczny: 121-195, Warszawa.

Kuenen, P.H., 1957. Sole markings of graded greywacke beds. Journal of Geology, 65: 231-258.

Labaume, P., Mutti, E., Seguret, M., 1987. Megaturbidites: a depositional model from the Eocene of the SW-Pyrenean foreland basin, Spain. Geo-Marine Letters, 7: 91-101.

Leszczyński, S., 1981. Cię kowice Sandstones of the Silesian Unit in Polish Carpathians: a study of coarse-clastic sedimentation in deep-water (in Polish with English summary). Annales Societatis Geologorum Poloniae, 51: 435-502.

Leszczyński, S., 1989. Characteristics and origin of fluxoturbidites from the Carpathian Flysch (Cretaceous-Palaeogene), South Poland. Annales Societatis Geologorum Poloniae, 59: 351-390.

Lexa, J., Bezák, V., Elečko, M., Mello, J., Polák, M., Potfaj, M., Vozár, J., eds., 2000. Geological map of Western Carpathians and adjacent areas 1:500 000. Geological Survey of the Slovak Republic, Bratislava.

Liebus, A., Uhlig, V., 1902. Über einige Fossilien aus der karpathischen Kreide (mit stratigraphischen Bemerkungen hierzu). Beiträge zur Paläontologie und Geologie Österreich-Ungarns und des Orients, 14: 113-130.

Lowe, D.R., 1982. Sediment gravity flows: II. Depositional models with special reference to the deposits of high-density turbidity currents. Journal of Sedimentary Petrology, 52: 279-297.

Martin-Chivelet, J., Fregenal-Martínez, M.A., Chacón, B., 2008. Traction structures in contourites. Developments in Sedimentology, 60: 159-182.

Matyszkiewicz, J., Słomka, T., 1994. Organodetrital conglomerates with ooids in the Cieszyn Limestone (Tithonian-Berriasian) of the Polish Flysch Carpathians and their paleogeographic significance. Annales Societatis Geologorum Poloniae, 63: 211-248.

Menčík, E., Tyráček, J., eds., 1985. Synoptic Geological Map of the Beskydy Mts. and the Podbeskydská Pahorkatina Upland, 1:100 000. Czech Geological Office, Geological Survey, Prague.

Menčík, E., Adamová, M., Dvořák, J., Dudek, A., Jetel, J., Jurková, A., Hanzlíková, E., Houša, V., Peslová, H., Rybářová, L., Šmíd, B., Šebesta, J., Tyráček, J., Vašíček, Z., 1983. Geology of the Moravskoslezské Beskydy Mts. and the Podbeskydská pahorkatina Upland (in Czech with English summary). Ústřední Ústav Geologický ČSAV, Praha.

Middleton, G.V., Hampton, M.A., 1973. Sediment gravity flows: mechanics of flow and deposition. SEPM Pacific Section Short Course: 1-38.

Mulder, T., 2011. Gravity processes and deposits on continental slope, rise and abyssal plains. Developments in Sedimentology, 63: 25-148.

Mulder, T., Faugčres, J.-C., Gonthier, E., 2008. Mixed Turbidite-Contourite Systems. Developments in Sedimentology, 60: 435-456.

Mutti, E., Ricci Lucchi, F., 1972. Turbidites of the northern Apennines: introduction to facies analysis. International Geology Review, 20: 125-166.

Mutti, E., Bernoulli, D., Ricci Lucchi, F., Tinterri, R., 2010. Reply to the Discussion by Ganapathy Shanmugam on "Turbidities and turbidity currents from Alpine flysch to the exploration of continental margins" by Mutti et al. (2009). Sedimentology, 57: 933-934.

Nemčok, M., Nemčok, J., Wojtaszek, M., Ludhova, L., Oszczypko, N., Sercombe, W.J., Cieszkowski, M., Paul, Z., Coward, M.P., Ślączka, A., 2001. Reconstruction of Cretaceous rifts incorporated in the Outer West Carpathian wedge by balancing. Marine and Petroleum Geology, 18: 39-64.

Nescieruk, P., Szydło, A., 2003. Rozwój i pozycja stratygraficzna warstw istebniańskich w Beskidzie Morawsko-Śląskim (in Polish). Sborník vědeckých prací Vysoké školy báňské, 49: 74-75. 
Olszewska, B., Wieczorek, J., 2001. Jurassic sediments and microfossils of the Andrychów Klippes (Outer Western Carpathians). Geologica Carpathica, 52: 217-228.

Oszczypko, N., 1999. From remnant ocean basin to collision-related foreland basin - a tentative history of the Outer Western Carpathians. Geologica Carpathica, 50: 161-163.

Paul, Z., Ryłko, W., Tomaś, A., 1996. Zarys budowy geologicznej zachodniej części Karpat polskich (bez utworów czwartorzędowych) (in Polish). Przegląd Geologiczny, 44: 469-476.

Pescatore, T., Ślączka, A., 1984. Evolution models of two flysch basins: the Northern Carpathians and Southern Apennines. Tectonophysics, 106: 49-70.

Peszat, C., 1976. Istebna sandstones (Campanian-Palaeocene) Kwartalnik AGH, Geologia, 2: 27-35.

Peszat, C., Wieser, T., 1999. Mineral composition matrix in thickbedded Istebna Sandstones (the Polish Flysch Carpathians). Mineralogica Polonica, 30: 73-83.

Picha, F.J., Stráník, Z., Krejčí, S., 2006. Geology and hydrocarbon resources of the Outer Western Carpathians and their foreland, Czech Republic. AAPG Memoir, 84: 49-175.

Poprawa, P., Malata, T., Oszczypko, N., 2002.Tectonic evolution of the Polish part of Outer Carpathian's sedimentary basins - constraints from subsidence analysis (in Polish with English summary). Przegląd Geologiczny, 50: 1092-1108.

Poprawa, P., Malata, T., Pécskay, Z., Kusiak, M.A., Banaś, M., Skulich, J., Paszkowski, M., 2004. Geochronology of crystalline basement of the Western Outer Carpathians' sediment source areas - preliminary data. Mineralogical Society of Poland, Special Papers, 24: 329-332.

Porębski, S.J., Steel, R.J., 2006. Deltas and sea-level change. Journal of Sedimentary Research, 76: 390-403.

Powers, M.C., 1953. A new roundness scale for sedimentary particles. Journal of Sedimentary Petrology, 23: 117-119.

Purvis, K., Kao, J., Flanagan, K., Henderson, J., Duranti, D., 2002. Complex reservoir geometries in a deep water clastic sequence, Gryphon Field, UKCS: injection structures, geological modeling and reservoir simulation. Marine and Petroleum Geology, 19: 161-179.

Rajchel, J., Uchman, A., 2012. Ichnology of Upper Cretaceous deep-sea thick-bedded flysch sandstones: Lower Istebna Beds, Silesian Unit (Outer Carpathians, southern Poland). Geologica Carpathica, 63: 107-120.

Rauch, M., 2013. The Oligocene-Miocene tectonic evolution of the northern Outer Carpathian fold-and-thrust belt: insights from compression-and-rotation analogue modelling experiments. Geological Magazine, 150: 1062-1084

Reading, H.G., 1986. Introduction. In: Sedimentary Environment Sand Facies, 2nd Edition (ed. H.G. Reading): 1-3. Blackwell Scientific Publications, Oxford.

Reading, H.G., Richards, M., 1994. Turbidite systems in deep-water basin margins classified by grain size and feeder system. AAPG Bulletin, 78: 792-822.

Rebesco, M., Camerlenghi, A., Van Loon, A.J., 2008. Contourite research: a field in full development. Developments in Sedimentology, 60: 3-10.

Sanders, J.E., 1965. Primary sedimentary structures formed by turbidity currents and related resedimentation mechanisms. SEPM Special Publication, 12: 192-219.

Sanders, J.E., Friedman, G.M., 1997. History of petroleum exploration in turbidites and related deep-water deposits. Northeastern Geology and Environmental Sciences, 19: 67-102.

Shanmugam, G., 1997. Slope turbidite packets in a fore-arc basin fill sequence of the Plio-Pleistocene Kakegawa Group: their formation and sea-level changes - discussion. Sedimentary Geology, 112: 297-300.

Shanmugam, G., 2000. 50 years of the turbidite paradigm (1950s-1990s): deep-water processes and facies models - a critical perspective. Marine and Petroleum Geology, 17: 285-342.
Shanmugam, G., 2006. Deep-water processes and facies models: Implications for sandstone petroleum reservoirs. Handbook of Petroleum Exploration and Production, 5, Elsevier, Amsterdam.

Shanmugam, G., 2008. Deep-water bottom currents and their deposits. Developments in Sedimentology, 60: 59-81.

Shanmugam, G., 2010. Discussion: "Turbidites and turbidity currents from Alpine flysch to the exploration of continental margins" by Mutti et al. (2009). Sedimentology, 56: 267-318.

Shanmugam, G., 2012. New Perspectives on Deep-water Sandstones. Elsevier, Amsterdam.

Shanmugam, G., Damuth, J.E., Moiola, R.J., 1985. Is the turbidite facies association scheme valid for interpreting ancient submarine fan environments? Geology, 13: 234-237.

Shanmugam, G., Moiola, R.J., 1988. Submarine fans: characteristics, models, classification, and reservoir potential. Earth-Science Reviews, 24: 383-428.

Słomka, T., 1995. Deep-marine siliciclastic sedimentation of the Godula Beds, Carpathians (in Polish with English summary). Prace Geologiczne, 139: 1-132.

Stanley, D.J., Kelling, G., eds., 1978. Sedimentation in Submarine Canyons, Fans, and Trenches. Dowden, Hutchinson and Ross, Inc. Stroudsburg, Pennsylvania.

Stow, D.A.V., Reading, H.G., Collinson, J.D., 1996. Deep Seas. Sedimentary Environments: Processes, Facies and Stratigraphy. Blackwell Science, Oxford.

Stow, D.A.V., Johansson, M., 2000. Deep-water massive sands: nature, origin and hydrocarbon implications. Marine and Petroleum Geology, 17: 145-174.

Strzeboński, P., 2005. Cohesive debrites of the Istebna Beds (Upper Senonian-Paleocene) west of the Skawa River (in Polish with English summary). Geologia, 31: 201-224.

Strzeboński, P., 2009. Sandstone-conglomerate rocky forms more than a tourist attraction (in Polish with English summary). Geoturystyka-Geotourism, 16-17: 49-60.

Strzeboński, P., 2012a. The Dorkowa Rock. In: The Catalogue of Geotourist Sites in Nature Reserves and Monuments (sc. ed. T. Słomka): 506-509. AGH University of Science and Technology, Kraków.

Strzeboński, P., 2012b. The Mushroom Rocks at the Równe. In The Catalogue of Geotourist Sites in Nature Reserves and Monuments (sc. ed. T. Słomka): 534-537. AGH University of Science and Technology, Kraków.

Strzeboński, P., 2012c. The Mushroom Rocks in the Sto ek Range. In: The Catalogue of Geotourist Sites in Nature Reserves and Monuments (sc. ed. T. Słomka): 538-541. AGH University of Science and Technology, Kraków.

Strzeboński, P., 2012d. The Rocks on the Kobyla. In: The Catalogue of Geotourist Sites in Nature Reserves and Monuments (sc. ed. T. Słomka): 542-545. AGH University of Science and Technology, Kraków.

Strzeboński, P., Słomka, T., 2007. The Rodło Cascades as a geotouristic attraction of the Silesian Beskid Mts. (in Polish with English summary). Geoturystyka-Geotourism, 8: 21-28.

Sullwold, Jr., H.H., 1961. Turbidites in oil exploration. In: Geometry of Sandstone Bodies (eds. J.A. Peterson and J.C. Osmond): 63-81. Tulsa, Oklahoma.

Ślączka, A., ed., 1986. Atlas of Paleotransport of Detrital Sediments in the Carpathian-Balkan Mountain System. Part II: Cenomanian-Senonian. Hungarian Geological Institute, Budapest.

Ślączka, A., Wilk, Z., Gradziński, R., 2001. Kronika Polskiego Towarzystwa Geologicznego - Rafał Unrug (1931-2000) (in Polish). Annales Societatis Geologorum Poloniae, 71: 135-137.

Ślączka, A., Kruglov, S., Golonka, J., Oszczypko, N., Popadyuk, I., 2006. The general geology of the Outer Carpathians, Poland, Slovakia, and Ukraine. AAPG Memoir, 84: 221-258.

Ślączka, A., Renda, P., Cieszkowski, M., Golonka, J., Nigro, F., 2012. Sedimentary basins evolution and olistoliths formation: The case of Carpathian and Sicilian regions. Tectonophysics, 568-569: 306-319. 
Talling, P.J., Masson, D.G., Sumner, E.J., Malgesini, G., 2012. Subaqueous sediment density flows: depositional processes and deposit types. Sedimentology, 59: 1937-2003.

Tripsanas, E.K., Bryant, W.R., Phaneuf, B.A., 2004. Slope-instability processes caused by salt movements in a complex deepwater environment, Bryant Canyon area, northwest Gulf of Mexico. AAPG Bulletin, 88: 801-823.

Uchman, A., 2009. The Ophiomorpha rudis ichnosubfacies of the Nereites ichnofacies: characteristics and constraints. Palaeogeography, Palaeoclimatology, Palaeoecology, 276: 107-119.

Unrug, R., 1963. Istebna Beds - a fluxoturbidity formation in the Carpathian Flysch. Annales Societatis Geologorum Poloniae, 33: 49-92.

Unrug, R., 1968. The Silesian cordillera as the source of clastic material of the Flysch sandstones of the Beskid Śląski and Beskid Wysoki ranges, Polish West Carpathians (in Polish with English summary). Annales Societatis Geologorum Poloniae, 38 81-164.

Unrug, R., ed., 1969. Przewodnik geologiczny po zachodnich Karpatach fliszowych (in Polish). Wyd. Geol., Warszawa.

Unrug, R., 1977. Ancient deep-sea traction currents deposits in the Lgota Beds (Albian) of the Carpathian Flysch. Annales Societatis Geologorum Poloniae, 47: 355-370.

Unrug, R., 1980. Ancient contourites in the Menilite Beds (Oligocene) of the Carpathian Flysch, Poland. Annales Societatis Geologorum Poloniae, 50: 175-182.
Wagner, R., ed., 2008. Tabela stratygraficzna Polski (in Polish). Karpaty. Państwowy Instytut Geologiczny, Warszawa.

Wentworth, C.K., 1922. A scale of grade and class terms for clastic sediments. Journal of Geology, 30: 377-392.

Wojewoda, J., 2008. Diffusional cells - an example of differentiated rheological reaction of granular sediment to seismic shock (in Polish with English summary). Przegląd Geologiczny, 56: 842-847

Wójcik, A., Kopciowski, R., Malata, T., Marciniec, P., Nescieruk, P., 1996. Propozycja podziału jednostek litostratygraficznych polskich Karpat zewnętrznych (in Polish). In: 67th Annual Meeting of Polish Geological Society, Western Beskidy Mts. - new approach to geological structure and natural resources (eds. D. Poprawa and W. Rączkowski): 209-215. Szczyrk, 6-9 czerwca 1996. Polskie Towarzystwo Geologiczne, Państwowy Instytut Geologiczny, Kraków.

ytko, K., Gucik, S., Ryłko, W., Oszczypko, N., Zając, R., Garlicka, I., Nemčok, J., Eliáš, M., Menčík, E., Dvořák, J., Stráník, Z., Rakus, M., Matějovská, O., 1989. Geological map of the Western Outer Carpathians and their foreland without Quaternary formations, 1:500,000. In: Geological Atlas of the Western Outer Carpathians and their foreland (eds. D. Poprawa and J. Nemčok). Państwowy Instytut Geologiczny, Warszawa. 